\title{
The Hulks and the Deadpools of the Cytokinin Universe: A Dual Strategy for Cytokinin Production, Translocation, and Signal Transduction
}

\author{
Tomáš Hluska $^{1, * \mathbb{C}}$, Lucia Hlusková ${ }^{1}\left(\mathbb{D}\right.$ and R. J. Neil Emery ${ }^{2}$ (D) \\ 1 Laboratory of Hormonal Regulations in Plants, Institute of Experimental Botany, The Czech Academy \\ of Sciences, Rozvojová 263, CZ-16502 Prague 6, Czech Republic; hluskova@ueb.cas.cz \\ 2 Biology Department, Trent University, Peterborough, ON K9L 0G2, Canada; nemery@trentu.ca \\ * Correspondence: hluska@ueb.cas.cz; Tel.: +420-225-106-436
}

Citation: Hluska, T.; Hlusková, L.;

Emery, R.J.N. The Hulks and the

Deadpools of the Cytokinin Universe: A Dual Strategy for Cytokinin Production, Translocation, and Signal Transduction. Biomolecules 2021, 11, 209. https://doi.org/10.3390/ biom11020209

Academic Editor: Guzel Kudoyarova Received: 15 January 2021

Accepted: 28 January 2021

Published: 3 February 2021

Publisher's Note: MDPI stays neutral with regard to jurisdictional claims in published maps and institutional affiliations.

\begin{abstract}
Cytokinins are plant hormones, derivatives of adenine with a side chain at the $N^{6}$-position. They are involved in many physiological processes. While the metabolism of trans-zeatin and isopentenyladenine, which are considered to be highly active cytokinins, has been extensively studied, there are others with less obvious functions, such as cis-zeatin, dihydrozeatin, and aromatic cytokinins, which have been comparatively neglected. To help explain this duality, we present a novel hypothesis metaphorically comparing various cytokinin forms, enzymes of CK metabolism, and their signalling and transporter functions to the comics superheroes Hulk and Deadpool. Hulk is a powerful but short-lived creation, whilst Deadpool presents a more subtle and enduring force. With this dual framework in mind, this review compares different cytokinin metabolites, and their biosynthesis, translocation, and sensing to illustrate the different mechanisms behind the two CK strategies. This is put together and applied to a plant developmental scale and, beyond plants, to interactions with organisms of other kingdoms, to highlight where future study can benefit the understanding of plant fitness and productivity.
\end{abstract}

Keywords: cis-zeatin; cytokinins; cytokinin biosynthesis; isopentenyl transferase; cytokinin oxidase/dehydrogenase; cytokinin signalling; aromatic cytokinins; cytokinin transport; Hulk/Deadpool

\section{Introduction}

Cytokinins (CKs) are plant hormones involved in many physiological processes. They are considered as one of the main groups of phytohormones as they, together with auxins, control cell division and, hence, influence the overall plant's architecture.

The first CK was discovered in the mid 1950s [1]. Its cytokinetic activity was detected from old and autoclaved DNA and the purified compound was named kinetin. This spurred a search for compounds, natural and synthetic, with similar activity. Interestingly, the first compound with CK-like activity isolated from a natural source (that is, apart from degraded DNA) was $N, N^{\prime}$-diphenylurea [2]. It was isolated from coconut milk, as that was previously recognised to induce cytokinesis. The coconut milk was, in fact, used in growth media before the discovery of CKs. However, the identified $N, N^{\prime}$-diphenylurea was probably present because of contamination as the coconuts were processed in a facility where urea herbicides had been previously synthesised [3]. To date, the presence of $N, N^{\prime}$ diphenylurea in the coconut milk has never been confirmed. On the other hand, the presence of the kinetin in coconut milk was validated [4]. However, kinetin was implied to originate by oxidative damage to DNA bases [5] and this is consistent with its discovery in old and autoclaved DNA; thus, it is likely not synthesised de novo as per other CKs.

Thus, the first unambiguously identified natural CK was zeatin [6], presumably the trans isomer, as the purification was followed by a bioassay for cell division (see below). 
There is a hypermodified nucleotide in many $\mathrm{tRNAs}$ forming $\mathrm{A}=\mathrm{U}$ pairing at the first position of the codon. While the tRNAs recognising UNN codons contain mostly CKs or wybutosine, a hypermodified guanine, those recognising ANN codons contain almost exclusively $N^{6}$-threonylcarbamoyladenosine. No such conservation is present in tRNAs binding to CNN or GNN codons [7].

The modifications in the anticodon loop of tRNA generally serve to improve codonanticodon reading and increased translation efficiency. The hypermodifications of purine at position 37 ( $N^{6}$-isopentenyl, $N^{6}$-threonylcarbamoyl and/or 2-methylthiol groups) facilitate the complementary codon binding [8]. In this way, it contributes to the modified wobble hypothesis [9].

CKs are present in tRNAs of organisms from all life kingdoms with the possible exception of Archea [10]. The CK is present at position 37 (A37), next to the anticodon. The modification occurs at the middle one of three adenosines. This is not the sole requirement though, as there are other unmodified adenosine triplets [11]. However, CKs are not present in all tRNAs of this type or even consistently in analogous tRNAs from different organisms [7].

The functions of CKs can be summarised as triggering cellular changes that are essential for numerous possible fates throughout the plant's life. This includes both developmental processes and adaptive responses to various abiotic and biotic inputs. The response is further influenced by crosstalk with other signals that vary with the cell's history and thus context [12].

\section{Hulks and Deadpools of the Cytokinin Universe}

In this paper, we are proposing a novel hypothesis describing a two-tier system of CK types, their metabolic enzymes, and signalling components to regulate plant growth and to distinguish between times of prosperity and times of compromise.

In the pop culture, one can encounter distinct Universes in which there are certain physics and figures who co-exist and may meet. In the Marvel Comics Universe, there are, among many others, Hulk who is incredibly strong and Deadpool who is immortally resilient (Figure 1). Both characters have superhuman powers. However, they have strikingly different abilities and roles. Hulk is a hyper-muscular humanoid possessing a vast degree of physical strength but only appears for relatively short-lived bursts of angry power while Deadpool is not extraordinarily physically strong but has immortal persistence derived from accelerated healing factors.

Throughout the Universe of the plant hormones known as the CKs, there seems to be a reoccurring theme of the strong but specialised "Hulk" versus the less active but more resilient "Deadpool" (Figure 1). Below we will illustrate the key differences with a few examples that will be corroborated in more detail in subsequent sections.

The activity of particular CKs may be described at two levels. First, CKs influence various physiological processes and this can be quantified in various bioassays. Second, CKs bind and activate their receptors, which is usually measured in heterologous systems. These two measures sometimes do not overlap. For example, O-glucosides or ribosides exert CK activity in various bioassays (e.g., [7]), but $O$-glucosides do not bind to receptors at all and ribosides very weakly $[13,14]$. They are active because they can be metabolised to the active forms. On the other hand, $N^{6}-\left(\Delta^{2}\right.$-isopentenyl)adenine (iP; all CK abbreviations are in accordance to Kamínek et al. [15]; see Supplementary Table S1) binds strongly to receptors, but it is not effective in preventing senescence in monocots (e.g., [16,17]).

Furthermore, the judgement about whether a particular CK exerts its activity through binding to $\mathrm{CK}$ receptor(s) is often reduced to comparisons of dissociation constants. However, even compounds with (relatively) higher dissociation constants may bind to the receptors even at (relatively) low concentrations. Of course, under such conditions, the receptors will not be saturated, but there will be certain output anyway, albeit suboptimal. The second factor, which is currently overlooked, is the duration of the signal. In this matter, a long-lasting weak signal may result in significant output. 


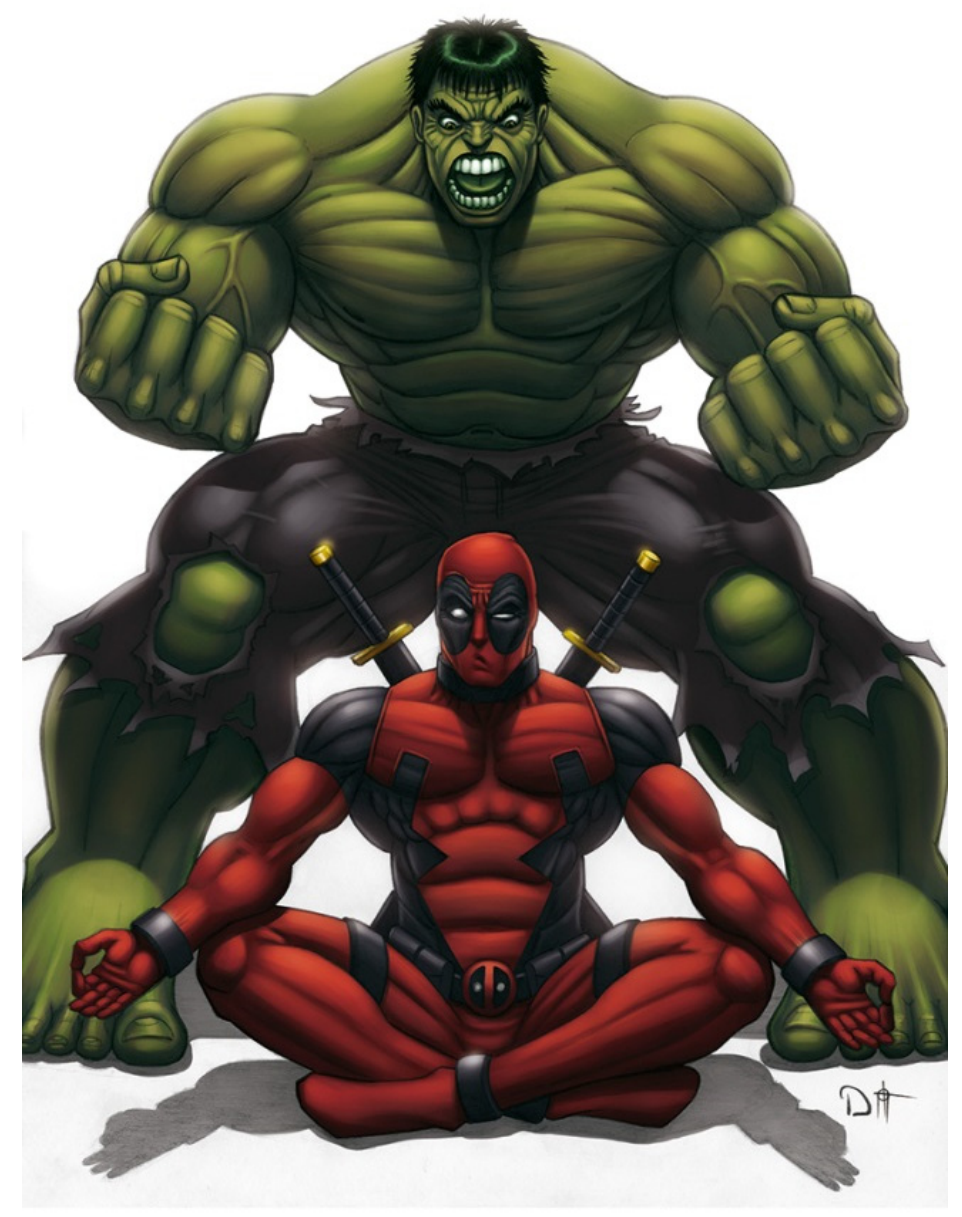

Figure 1. Hulk and Deadpool of the Marvel Universe. Hulk is strong, and uses bursts of brute force. Deadpool on the other hand is resilient due to his immortality. Are there Hulks and Deadpools in the Cytokinin Universe? Drawn by David Ocampo.

On the one hand, there are the highly active Hulk CKs, trans-zeatin ( $t \mathrm{Z})$ and iP, which are capable of inducing a burst of growth, and levels of which are tightly controlled by cytokinin oxidase/dehydrogenase (CKX) or other deactivating enzymes. On the other hand, there are Deadpools, such as cis-zeatin $(c Z)$ and aromatic $\mathrm{CKs}$, which are, in general, weak substrates, and thus less likely to be destroyed by CKX [18,19]. However, this resistance/lower vulnerability to deactivation makes the feeble signal of the Deadpool CKs persistent (i.e., as demonstrated for Rhodococcus; [20]). It may be that the function of $c \mathrm{Z}$ in stress signalling is to simply "knock-out" the interaction of the strong Hulk CKs with enzymes of CK metabolism or with receptors. This would have a dual effect. By competing for binding to receptors, it may diminish CK signalling during stress until more favourable conditions occur; while there would also be competition for binding to inactivation enzymes, such as glycosylase or CKX, and in effect it would prevent degradation or conjugation of the Hulk CKs. This may be favourable for said Rhodococcus.

The apparent strength of respective enzymes, receptors, or transporters can be similarly judged by comparisons of their activities and the corresponding in planta spatiotemporal expression patterns. Accordingly, the Hulks are expressed and/or localised in a more focused matter and exert high activity, while the Deadpools have more widespread expression with rather low activity, which consequently yields more uniform output.

For example, the expression of AtIPT3 is strongly upregulated upon nitrate re-supply as a signal for fast growth while the resources are available. On the other hand, the expression of IPT5 orthologues is more uniform and their activity is rather low [21,22]. Thus, although they produce $t Z$ and/or iP [23], they provide a more constant supply of 
CKs. Indeed, AtIPT5 expression correlates with nitrogen concentration in media when supplemented continuously [24].

Next, the Lonely guy (LOG) proteins are capable of quickly and specifically activating CKs (almost) directly from their biosynthetic forms [25] and thereby act as Hulks; yet, there is the possibility of two-step activation (de-phosphorylation followed by deribosylation), which may originate simply from a plant's inability to regulate any nonspecific activity. However, as discussed below, while this Deadpool two-step activation may be less responsive, it nonetheless retains physiological significance.

Likewise, the $\mathrm{CK}$ receptors on the plasma membrane perceive long-range Hulk signals, while the ER localised receptors likely perceive mainly the autocrine Deadpool signal. Interestingly, recently described CK receptors from apple trees (Malus domestica), MdCHK3a and $M d C H K 3 b$, show constitutive activity, which may be enhanced by added CKs [14]. Their expression was detected in all tissues tested, but it was about 100-times lower than of MdCHK2, the most active and expressed member of the CK receptor family in apple trees. This would be an exemplary case of Deadpool signal transduction. There also appears to be low- and high-affinity transport of CKs in plants, as the CK uptake rates show multiphasic characteristics [26].

Thus, to expand the previously published hypothesis that $c Z$ is important under growth-limiting conditions $[27,28]$, we are presently proposing an extension of that hypothesis, whereby there are two sets of metabolites, enzymes, transporters, and percep-tion relays for CKs (Table 1). While one, including but not limited to $t Z$, iP, AtIPT3, and AtLOG7, is highly active and has specialised functions in promoting and regulating rapid growth ("Hulk"), there is another including but not limited to $c \mathrm{Z}$, aromatic CKs, and AtLOG8 that is involved in maintenance growth ("Deadpool").

Table 1. Examples of Hulks and Deadpools.

\begin{tabular}{|c|c|c|}
\hline Hulks & Deadpools & Commentary \\
\hline$t \mathrm{Z}, \mathrm{iP}$ & $\begin{array}{c}c \mathrm{Z} \\
\text { aromatic cytokinins }\end{array}$ & $\begin{array}{l}\text { While } t Z \text { and iP induce large changes in plant physiology, } c Z \text { and aromatic } \\
\text { cytokinins are "slow" with weak CK activity, but they are resistant and } \\
\text { thus persistent. }\end{array}$ \\
\hline AtIPT3 & $\begin{array}{l}\text { AtIPT5, SlIPT3 and } \\
\text { PpIPT5a } \\
\text { tRNA IPTs }\end{array}$ & $\begin{array}{l}\text { AtIPT3 is the main enzyme synthesising CKs with spatio-temporally focused } \\
\text { production; on the other hand, IPT5 orthologues are expressed widely but they } \\
\text { have only low activity, thus producing small less focused amounts of CKs. } \\
\text { tRNA IPTs usually exert wide expression and they produce the Deadpool } c Z \text {. }\end{array}$ \\
\hline receptors on PM & receptors on ER & $\begin{array}{l}\text { PM-localised receptors may perceive the Hulk CKs } t Z \text { and iP with very high } \\
\text { activity. To diminish Hulk signalling when Hulk CKs are not present, AHK } 4 \text { also } \\
\text { possesses a phosphatase activity. On the other hand, ER-localised receptors } \\
\text { perceive autocrine Deadpool signals. }\end{array}$ \\
\hline & & $\begin{array}{l}\text { LOGs activate CKs (almost) in a single step from biosynthesis products } \\
\text { specifically in regions of high cell division activities, while the two-step }\end{array}$ \\
\hline LOGs & two-step activation & activation functions throughout the plant body at low speed. Among LOGs, one \\
\hline AtLOG7 & AtLOG8 & $\begin{array}{l}\text { can distinguish AtLOG7 with high activity and expression focused to high } \\
\text { activity hotspots and AtLOG8 with minimal activity but expression throughout } \\
\text { the plant. }\end{array}$ \\
\hline
\end{tabular}

This hypothesis was formulated based mostly on data from Arabidopsis, because most of the foundational data come from that species. While enzyme, receptor, and transporter orthologues will probably work similarly (i.e., could be classified as Hulk or Deadpool in analogy to their Arabidopsis counterparts), this does not have to be the case for metabolites. For example, certain plants contain predominantly cis-zeatin. In such plants, it may function more as a Hulk CK as discussed below. Thus, it is possible that in other organisms, certain metabolites, but possibly also enzymes, transporters, or receptors, would be categorised differently than in Arabidopsis (Table 1).

Furthermore, the categorisation of some features may shift based on the magnitude of "scale". For example, in the CK activation landscape, the LOGs would be generally 
perceived as Hulks; however, AtLOG8 has the weakest activity among them, yet its expression level is also the highest [25]. Therefore, it substantially activates small amounts of CKs throughout the plant similarly to the two-step activation pathway.

This Hulk/Deadpool two-tier system could reflect the layers of growth strategies, powerful, short-lived, and focused on the one hand and persistent and pervasive on the other hand. It furthermore serves the source/sink relationships among plant organs, which sometimes necessitate rapid growth for fecundity (i.e., filling seeds) but cannot come at a cost to critical but slower growing spots (i.e., vegetative tissue maintenance). Overall, it reflects the original defining characteristics of $\mathrm{CKs}$, which were primarily discovered for their cytokinetic properties.

\section{Cytokinin Types}

Cytokinins are a family of compounds derived from adenine with a side chain at the $N^{6}$-group. This side chain defines two groups of CKs (Figure 2). Modifications of the side chain further define particular CK types and their metabolism and biological activity.

\subsection{Cis or Trans-That's What Matters}

The first CK isolated from a natural source was zeatin obtained from immature seeds of sweet corn (Zea mays, hence the name; [6]). As the hydroxymethyl group is positioned at a double bond, zeatin forms two geometric isomers. Quickly, it was established that the highly active compound was trans-zeatin. Soon, cis-zeatin was identified in tRNA [29]. However, its activity in the classical bioassays was miniscule [30-32]. Additionally, the activity of several enzymes of CK metabolism (especially of the catabolic CKX) towards $c Z$ was often negligible and thus cis-zeatin was often neglected.

Over the years, however, the number of reports of plants or plant organs containing predominantly the $c Z$-type CKs has kept growing. This includes potatoes [33-36], unfertilised hop cones [37], rice [38,39], chickpea and white lupine [40,41], maize [19,42,43], Tagetes minuta [44,45], pea [46], Lolium rigidum [47], lucerne and oats [48], oilseed rape [49], and Norway spruce somatic embryos [50]. The large-scale analyses in the plant kingdom [27], bryophytes [51], and in cyanobacteria and algae [52] revealed that the $c Z$ dominance is not a unique trait. Further, in other kingdoms of life, such as fungi, $c Z$ is often the major CK type [53].

Beyond their frequent predominance there are many examples that $c Z$ types can alter growth and development. For example, plants lacking $c Z$ display altered phenotypes, which suggests the significance of $c Z$ in planta. This may be achieved either through decreased $c Z$ biosynthesis or its increased degradation. Thus, Arabidopsis with decreased production of $c Z$ were often chlorotic [54] and the leaves of plants with increased $c Z$ degradation displayed visible stress symptoms and accumulation of anthocyanin [55]. Moreover, both types of plants showed aberrant root development with a shorter primary root [55]. This is in strong contrast to the increased primary root length of other lines with decreased levels of $\mathrm{iP}$ and $t Z[54,56]$. It must be noted that the lines with decreased $c Z$ biosynthesis are mainly affected in the levels of CKs in tRNA and the plants with increased $c Z$ degradation also have decreased levels of other types of CKs. However, $c Z$ was shown to complement the root developmental abnormalities, similarly to $t Z$, albeit at higher concentrations [55]. Moreover, $c Z$ shows activity in systems that are relevant to it (i.e., where they are at high levels). For example, the development of pea embryos is promoted by $c Z$ [46]. $c Z$ was also shown to inhibit the growth of roots of $c Z$-dominant rice, a response that is considered typical for CKs [38]. 


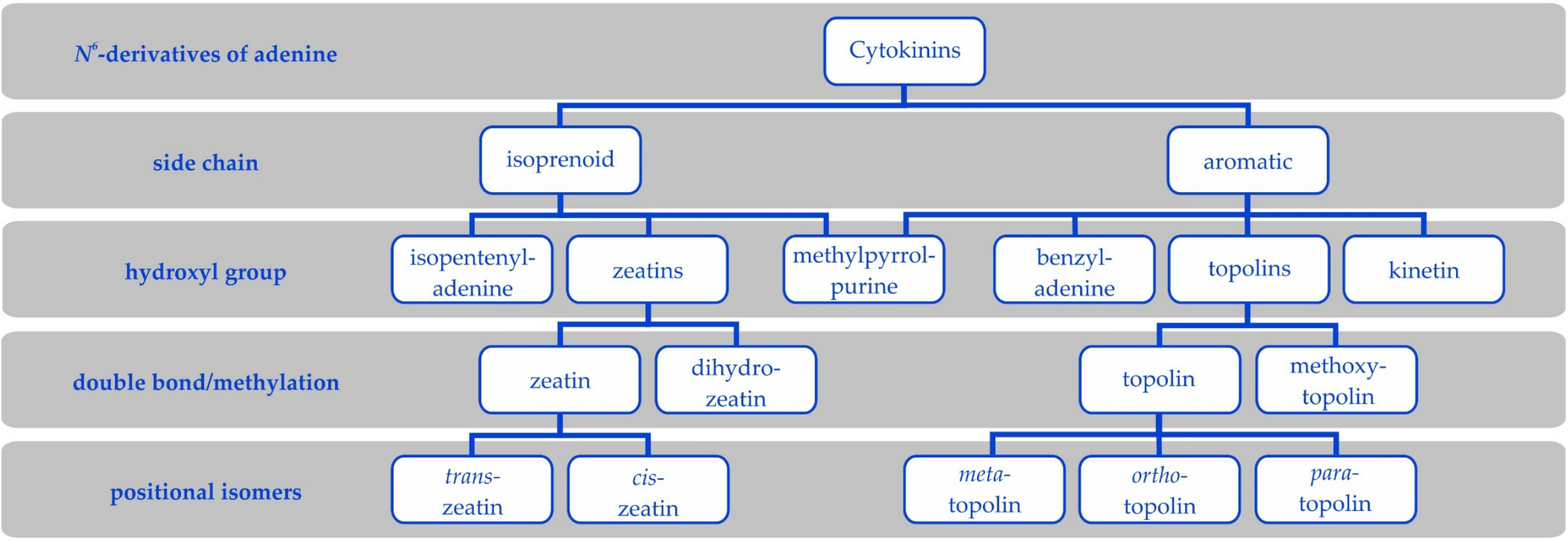

Figure 2. Cytokinin types. Cytokinins are $N^{6}$-derivatives of adenine either with isoprenoid or aromatic side chains. A hydroxyl group further differentiates zeatins from isopentenyladenine and topolins from benzyladenine. Further, kinetin is an aromatic cytokinin and 6-(3-methylpyrrol-1-yl)purine is at the borderline of isoprenoid and aromatic cytokinins, because it has an aromatic side chain but originates from trans-zeatin. Methoxytopolins exist in analogous isomers as topolins. 
The low activity in bioassays and low content in some plants might suggest that $c Z$ is indeed only an artefact from tRNA hydrolysis, without physiological significance, and that the interaction with CK enzymes is merely because of their low ability to discriminate between the isomers. When $c \mathrm{Z}$ was found to be active in some bioassays, it was usually explained by isomerisation to the trans-isomer. However, the discovery of the first enzyme highly specific towards $c Z$ [57] has unambiguously shown that its levels must be regulated by the plant and it is, thus, physiologically relevant. Additionally, the direct interaction of $c Z$ with CK receptors [58,59] showed that it is solely responsible for its own activity. Even though the majority of CKX enzymes degrade $c Z$ inefficiently, there are few isoenzymes that react with $c Z$, and some of them even preferentially over the other CKs $[19,27,55]$. Thus, if trans-zeatin were the "big and strong brother" of the Zeatins family, the cis-zeatin would be the, maybe weaker, yet more resilient brother.

A possible objection to the idea that $c Z$ is synthesised mainly or exclusively via tRNA is that it would be a waste of energy and resources for the plant (in terms of the synthesis of tRNA for the production of significant amounts of hormone). However, as the plant tRNA contains mainly cis-zeatin (see below and [54]), which is the main CK involved in stress responses (as reviewed by Schäfer et al. [28]), it is logical that a specific compound (i.e., not unmodified nucleotides) released from RNA can serve as a stress signal because the RNA hydrolysis is stress sensitive [60]. In this manner, $c Z$ works downstream of some primary response, which causes the RNA hydrolysis. Possibly, the sole function of $c Z$ in stress signalling may be simply to "knock-out" the strong Hulk signal by competing on CK receptors, until more favourable conditions occur.

Moreover, regular RNA turnover keeps the level of $c Z$, which may serve as the maintenance Deadpool signal. Furthermore, $c Z$ has an advantage to serve as both a stress and maintenance signal, because the plant already possesses a response system that slightly cross-reacts to it, unlike any other modified RNA bases.

Since the relevance of $\mathrm{tRNA}$-derived CKs is debatable, it was proposed that CKs were first present in tRNA for translation efficiencies, and only later acquired functions as hormones [61]. Plants needed to avoid interference of their developmental processes with tRNA turnover and this may have been achieved in mainly three ways [62]:

I Reduction of tRNA species bearing CK-like modifications and replacement with others, such as wybutosine.

II Preference for cis-zeatin over iP in tRNA.

III Modulation of CK perception to prefer trans-zeatin.

Thus, while bacteria contain CKs in most of their tRNAs recognising UNN codons, either as iP or $c Z$, depending on the presence of the MiaE gene (cf. Escherichia coli and Salmonella typhimurium), plants' tRNAs contain relatively few CKs and the majority is present as $c Z$ [54].

The importance of the tRNA-derived CKs has been demonstrated only recently. The Bradyrhizobium sp. strain ORS285 miaA mutant showed delayed development of nodules on Aeschynomene plants [63]. Similarly, the cptrna ipt mutant showed decreased virulence. Formation of sclerotia, the dormant stage of the fungus, was retarded and the majority of sclerotia were white and soft [64].

\subsection{Dihydrozeatin}

The reduced form of zeatin-dihydrozeatin (DHZ) - is considered less active than trans-zeatin [7]. Yet, it was first isolated from yellow lupine immature seeds following activity measurement using the tobacco callus bioassay $[65,66]$ and showed a substantial activity in other works [30,31]. In fact, it was the most active isoprenoid CK in a Phaseolus vulgaris bioassay [30]. In the same assay, isopentyladenine, a saturated analogue of iP, was 100-times more active than its parent compound. Further, it is capable of activating at least some CK receptors, especially the HK3 orthologues [58,67-70].

Despite its potential importance, DHZ is omitted from many analyses and hypotheses nowadays (e.g., [23,54]). This is probably because of its generally low measured quantities 
and because of a complete lack of knowledge about its metabolism. For example, there are only three publications dealing with the zeatin reductase, the putative DHZ biosynthetic enzyme, published over the course of 35 years [71-73]. We do not even know how DHZ is removed from the plant, as it is resistant to degradation by CKX [18]. Conversion of $\mathrm{DHZ}$ to adenine and/or adenosine was reported only rarely $[74,75]$. Otherwise, there is no evidence of other conversions besides glycosylations.

Dormant seeds often contain CKs with lower activity, such as cis-zeatin $[27,40,46,48]$ or dihydrozeatin $[19,40,48,76]$. There seems to be a pattern of $t Z$-dominant plants having $c Z$ in their seeds and $c Z$-dominant plants having DHZ in their seeds, although more widespread analysis would be necessary.

All of this together positions DHZ at the borderline of Hulks and Deadpools. It is highly active in bioassays, hence acting as Hulk, but only in a few known processes. Moreover, it is probably produced only at low rates. Furthermore, it is resistant to deactivation and thus acting as Deadpool, at least in Arabidopsis. Therefore, DHZ is an adjunct in the Zeatins family that only few researchers are talking about.

Lately, the authors have encountered a few times the notion that DHZ is not isoprenoid $\mathrm{CK}$ because of the saturated side chain. Although the information on zeatin reductase is scarce, as long as we do not have evidence for another origin of DHZ, we must assume that it originates from $t Z$ reduction and thus belongs to the isoprenoid CKs.

\subsection{Aromatic Cytokinins}

Aromatic cytokinins are adenine derivatives with an aromatic side chain (Figure 2). They include $N^{6}$-benzyladenine (BAP) and its hydroxyderivatives called topolins and their methoxyderivatives [77,78], $N^{6}$-furfuryladenine (kinetin; [4,79]), and the recently (re-)discovered 6-(3-methylpyrrol-1-yl)purine (MPP) and its derivatives [80-82].

Unlike the metabolism of isoprenoid CKs that has been extensively studied, the metabolism of aromatic CKs, especially their biosynthesis, is largely unknown. This is partly because of their scarce occurrence and hence lack of a suitable model for their study. So far, they are known to be very weak substrates for the CKX $[18,83]$. This is why they are very effective as morphogens in various in vitro culture techniques. While meta-topolin mimics $t Z$ both in $O$-glucosylation reaction and receptor recognition, ortho-topolin similarly mimics $c Z$ [84].

Since poplar trees are known to synthesise aromatic CKs, there was an effort to see if poplar isopentenyl transferases (IPTs) were special in that regard. It was concluded that the IPT enzymes are not responsible for biosynthesis of BAP-derived CKs because Arabidopsis transformed with poplar IPTs did not contain any aromatic CKs [22]. Nonetheless, when produced in Arabidopsis, the poplar enzymes may have simply lacked the appropriate substrate for the synthesis of aromatic CKs. Paradoxically, unambiguous information about biosynthesis exists only for the newest aromatic CK-MPP. It is synthesised directly from trans-zeatin, although the biosynthetic enzyme was not purified nor identified due to its instability [81]. In this regard, its origin from $t Z$ makes it interestingly in fact an isoprenoid CK.

It has been shown that MPP is capable of binding both to CK receptors and to CKX, although it neither activates them nor is it a substrate of CKX [81]. Thus, it has a dual role. It decreases the response of $\mathrm{CK}$ receptors; but, by inhibiting $\mathrm{CKX}$, it extends the $\mathrm{CK}$ response. As MPPR and MPP9G are present in amounts comparable to other CKs, their effect on CKX may be even more substantial as ribosides and N9-glucosides are often preferred substrates of CKX. On the other hand, they will not affect the receptors, which normally do not bind N9-glucosides and only weakly bind ribosides. However, MPPR and MPP9G probably will not be able to bind to CKX in the same unique way as was reported for MPP. So, the question remains: would they be able to inhibit CKX?

In addition to the $c Z$ - and DHZ-types, plant seeds are often reported to contain aromatic CKs. This holds for examples like kinetin found in the liquid endosperm of coconut (for a review, see [85]), MPP in the seeds of maize [81], and BAP and topolins 
in Tagetes minuta [44,45], pea [86], the seeds of maize, oat and lucerne [48], and in many other plant species [86]. This suggests that aromatic CKs may perform a common role in seed germination.

The natural occurrence of aromatic CKs has been shown in only a few select plants, algae, and microorganism species $[22,45,48,77,78,87,88]$. For example, derivates of orthotopolin were identified by at least four independent groups in various plants [22,89-91]. However, in many cases, their detection in living samples might be the result of labware contamination due to their massive usage in in vitro culturing. It was hypothesised that the aromatic CKs in plants may in fact originate from symbiotic bacteria. In accord with this hypothesis, BAP was reported to be secreted by nematodes [92] that are known for their intimate interactions with bacteria [93]. The bacterial origin would explain the inconsistency in the detection of aromatic CKs in various plants.

Another option is that aromatic CKs may originate from nucleic acids. For starter, orthotopolin was reported in the form of 2-methylthio-derivative [90]. The 2-methylthio-CKs are currently thought to originate solely from tRNA hydrolysis. Further, one laboratory has identified ortho-topolin directly in the RNA of algae Chlorella sorokiniana [94] and poplar [22]. Interestingly, the content of aromatic CKs was shown by some of the same researchers to change during daytime [22,78].

\section{Cytokinin Biosynthesis}

The biosynthesis of CKs starts with the addition of a side chain to an adenine either in nucleotide form or bound in tRNA. Several additional steps are generally included in the $\mathrm{CK}$ biosynthesis as hydroxylation of the side chain or reduction of the double bond in trans-zeatin's side chain (Figure 3).

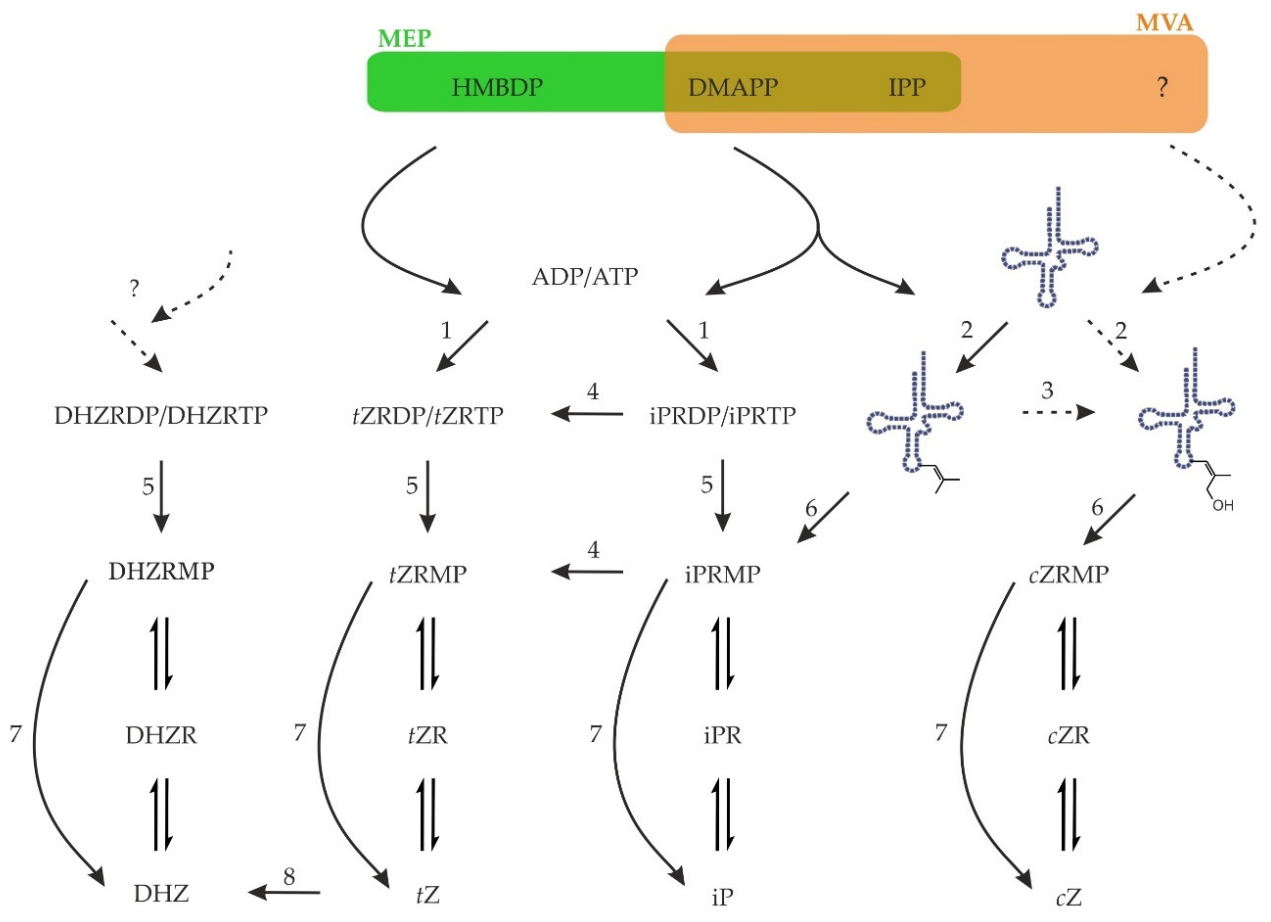

Figure 3. Biosynthesis and activation of cytokinins in plants. Precursors for CK biosynthesis, HMBDP and DMAPP, come either from the methylerythritol (MEP) or mevalonate (MVA) pathways. Plant adenylate IPTs (1) utilise mostly ADP or ATP whereas tRNA IPTs (2) use the adenine in position 37 of certain tRNAs as acceptor substrate. cis-Zeatin is known to originate from tRNA, but its synthesis is unclear, as neither a cis-hydroxylated precursor nor cis-hydroxylase (3) have yet been identified in plants. Nucleotides of iP may be hydroxylated by cytochrome P450 (4) to form $t Z$. Upon hydrolysis of $\gamma$ and $\beta$-phosphates (5) or tRNA hydrolysis (6), the resulting monophosphates may be activated in one step by CK-specific phosphoribohydrolase named Lonely guy (7). Alternatively, the nucleotides, nucleosides, and nucleobases are probably interconverted by enzymes of purine metabolism. The free base $t Z$ may be reduced to DHZ by zeatin reductase (8). Whether there is any de novo biosynthesis of DHZ is currently unknown. Zeatin cis-trans isomerase does not exist. 
The most recent research has been focused on Arabidopsis and on iP and $t Z$ as the main active CKs [95] and, thus, there has been a significant bias to their reporting. As has been mentioned above, the synthesis of $\mathrm{DHZ}$ from $t \mathrm{Z}$ has received very little attention so far and the de novo biosynthesis of aromatic cytokinins remains an enigma. Another example is the assumption of strict preference of the precursor's biosynthetic pathway used for synthesis of $\mathrm{PP}$ and $t Z$ or $c Z$, when in fact the majority of living organisms have only one biosynthetic pathway operational with the exception of green plants and only a handful of microorganisms [96,97]. Yet, although fungi, animals, and some bacteria do not possess the methylerithrytol pathway purportedly responsible for iP and $t Z$ precursor synthesis and/or they lack enzymes for de novo CK synthesis, most of them produce the full spectrum of CKs.

\subsection{Isopentenyltransferase}

The first step of CK biosynthesis is catalysed by isopentenyltransferases. The correct name is dimethylallyltransferase, as dimethylallyl pyrophosphate (DMAPP) is the substrate, rather than $\Delta^{3}$-isopentenyl diphosphate (IPP). However, throughout this work, the commonly used name isopentenyltransferase (IPT) is used.

The addition of the isoprenyl side chain is widely referred to as the rate-limiting step of CK biosynthesis [98]. Considering that the free bases are usually present in minute quantities while the ribosides and ribotides are often present in much higher quantities, it seems probable that another step in the CK biosynthesis/activation process is the bottleneck.

There are currently three classes of isopentenyltransferases recognised to be involved in CK biosynthesis: adenylate dimethylallyltransferase (AMP-dependent; EC 2.5.1.27), tRNA dimethylallyltransferase (EC 2.5.1.75), and adenylate dimethylallyltransferase (ADP / ATP-dependent; EC 2.5.1.112). At this moment, only the tRNA IPTs seem to strictly adhere to the single activity of dimethylallyl pyrophosphate:adenine ${ }^{37}$ in tRNA dimethylallyltransferase. The adenylate IPTs, on the other hand, are enzymes utilising multiple substances both as acceptor and as donor substrates.

In plants, there are two pathways providing isoprenoid units with distinct localisation and usage of the products. The first one is the mevalonate pathway (MVA), which operates in the cytosol of plants and is present also in animals, fungi, Archea, some bacteria, Trypanosoma, and Leishmania. The end-product is IPP, which can be freely isomerised to DMAPP. No hydroxylated intermediate was found to date in this pathway. The second pathway is called the methylerythritol pathway (MEP) or non-mevalonate pathway and operates in the plastids of plants, in green algae, and in the majority of bacteria. A series of steps leads to $(E)$-4-hydroxy-3-methylbut-2-enyl diphosphate (HMBDP), which is ultimately reduced to yield either IPP or DMAPP. There is an exchange of IPP and DMAPP among the compartments of the plant cell to some extent [99]. DMAPP and HMBDP serve as side-chain donors in iP and $t Z$ biosynthesis, respectively [100].

In reports concerned more with the IPT enzymology than the CK function, a wider substrate specificity was reported, including mono-, di-, and tri- nucleotides of purine and pyrimidine bases [101,102]. Interestingly, the HlIPT from hop is capable of binding diadenosine polyphosphates and using them as substrates. It is even capable of forming diisoprenylated product [103]. MaIPT from mulberry prefers the DMAPP as the donor substrate, but it is capable of also using HMBDP, geranyl pyrophosphate $\left(\mathrm{C}_{10}\right)$, and IPP. Farnesyl pyrophosphate $\left(\mathrm{C}_{15}\right)$ is not an acceptable substrate for MaIPT [101]. The HlIPT possesses a large cavity, which could also able to accommodate geranyl pyrophosphate [102]. Of course, one can neglect this as an artefact without physiological significance. However, nonetheless, it would be interesting to see whether, for example, enzymes from Arabidopsis would be able to utilise similar substances as substrates and/or whether mulberry or hop contain CK-like compounds derived from these substances. Afterall, $N^{6}$-farnesyladenine and $N^{6}$-geranyladenine displayed activity in a tobacco callus bioassay [104].

Although it was assumed in the past that CKs are synthesised in the root and transported to the aerial organs, expression analysis showed that IPT expression is widespread 
throughout the whole plant $[24,43,105-110]$. It is also responsive to other hormones, mostly auxin $[105,107,108,111,112]$, and to some nutrients, mostly to nitrate [24,105]. Recently, it was shown how nitrate promotes plant growth through IPT expression and CK production $[113,114]$.

Besides differential expression, the proteins are localised to various subcellular compartments. With the exception of cytosol-localised AtIPT4 and mitochondria-localised AtIPT7, the remaining Arabidopsis adenylate IPTs were shown to be localised to plastids [23]. However, this result was based on C-terminal fusion with green fluorescent protein (GFP). When the GFP was fused to the N-terminus, AtIPT3 was localised to the nucleus due to farnesylation [115]. A non-farnesylable C333S mutant was placed in plastids, unless it lacked the chloroplast transit peptide. In this case, it was localised in the cytoplasm [115]. Similarly, the closest homologue in poplar, PcIPT3, is the only poplar IPT containing CLVA peptide [22]. It was hypothesised that the dual localisation may be a regulation dependent on the relative availability of isoprenoid units coming from MVA and MEP pathways [115].

The kinetics of IPT enzymes have never been studied in as much detail as, for example, those of the CKXs and thus the importance of the different isoforms is difficult to judge. However, the Hulk AtIPT3 clearly stands out with its strong upregulation upon renewal of nitrogen $[24,105]$ serving as a signal for fast recovery of growth. Intriguingly, the double localisation of AtIPT3 may be the mechanism that ensures sufficient amounts of substrate for production of the Hulk signal. On the other hand, expression of AtIPT5 positively correlates with nitrogen availability in the long run [24]. In general, expression of IPT5 orthologues, AtIPT5, SIIPT3, and PpIPT5a, is widespread [21,22,105], although it is low in some cases and the enzyme activity is rather low. As a matter of fact, expression of AtIPT5 and 7 is upregulated by auxin [105], which generally counteracts CKs. Thus, IPT5 orthologues seem to be the omnipresent Deadpool signal indicating sufficient nutrients for stable growth and balancing of auxin action. Similarly, tRNA IPTs are, at least in Arabidopsis, responsible for the production of the Deadpool $c Z$ [54]. Hence, they could be classified as Deadpool. Indeed, they are usually widely expressed (e.g., [43,105]).

\subsection{Hydroxylation of Isopentenyladenine}

In the iP-dependent pathway, zeatins are formed by hydroxylation of the side chain.

This was first observed in the culture of the fungus Rhizopogon by Miura and coworkers [116,117]. Later, such activity was observed in microsomal fraction from cauliflower [118]. NADPH-dependent microsomal proteins converted iP riboside (iPR) to $t Z$ riboside $(t Z R)$ and iP to $t Z$. It was deduced, that cytochrome P450 monooxygenase (CYP) is responsible for the reaction, as it was inhibited by metyrapone, ethylene, and CO [118]. Later, two such CYPs were identified in Arabidopsis [119]. The enzymes utilise nucleotides of iP, mainly as mono- and diphosphates. Free base and riboside were very weak substrates. The only products detected in vitro were $t Z$-type CKs. Interestingly though, Saccharomyces cerevisiae expressing AtIPT4 with the cytochromes also contained a significant amount of DHZ-type CKs.

Both genes are expressed mainly in the roots and their expression is upregulated by $\mathrm{iP}$ and $t Z$ and downregulated by auxin and abscisic acid [119]. It was confirmed that the AtCYP735As are major contributors to trans-zeatin synthesis, since a double knock-out mutant had $<5 \%$ of $t Z$-type CKs, while iP-type CKs were increased to $~ 200 \%$ [120]. The mutant's phenotype resembled the phenotype of other CK-deficient or CK-insensitive mutants ipt3 57 and ahk2 3. Although the plant's growth was affected mainly in the shoot and barely in the root [120], it showed defects in lateral root primordia positioning [121]. The phenotype could be rescued by supplementation of $t Z$, but not iP or DHZ, thus reflecting the lack of $t Z$ as the causative agent of the phenotype [120].

\subsection{Cis-Zeatin-Unde es?}

Unlike the biosynthesis of $t Z$ and iP, the biosynthesis of cis-zeatin remains a mystery. Nowadays, it is accepted that $c Z$ originates from tRNA [54]. However, that does not answer 
the question —where does the cis-hydroxylated side chain originate from? There are, in principle, four possibilities for cis-zeatin biosynthesis:

(1) Isoprenylation of adenine, either free or tRNA-bound, with (Z)-4-hydroxy-3-methylbut2-enyl diphosphate.

(2) cis-hydroxylation of iP, either free or tRNA-bound.

(3) Isomerisation of $t \mathrm{Z}$.

(4) Dehydrogenation of dihydrozeatin.

The first two options are analogies to $t \mathrm{Z}$ biosynthesis. A cis-hydroxylase is known to act upon iP in tRNA [122]. The gene was named MiaE in Salmonella typhimurium. In general, the gene is present only in few species, such as Nostoc [123]. However, no MiaE homo-logue has been identified yet in plants. Thus, there is no evidence for either of the two options to function in planta at the moment.

Zeatin cis-trans isomerase was described [124], but neither the gene nor protein were identified. Thus, it was mentioned only when the discrepancy in data was floppily explained [59,82,125-127], but its existence was recently disproved [128]. Indeed, a majority of the in planta evidence is against the existence of zeatin cis-trans isomerase $[23,27,54,59,129,130]$, with the exception of a few cases involving applications of high CK concentrations whereupon the plant does not manage to control the metabolism, opening the possibility for non-enzymatic reactions $[22,34,38,81,131]$.

The last option is merely a hypothetical possibility; no such enzyme has ever been reported. However, dihydrozeatin is resistant to CKX cleavage [18,19,132], but it disappears during seed imbibition and following seedling growth. Thus, it was hypothesised that DHZ could serve as a source of active CKs before de novo biosynthesis starts [133]. Indeed, there was an attempt to measure the putative dihydrozeatin oxidase. Although no $t Z$ or $c Z$ was detected, a substantial amount of adenine was formed as a consequence of substrate degradation [134]. Accordingly, Podlešáková et al. [75] reported conversion of DHZ9G to adenine in maize.

Thus, cis-zeatin biosynthesis remains a big unknown in the CK world.

\section{Activation of Cytokinins}

The CKs are synthesised as nucleotides, but free bases are the active forms. Thus, hydrolysis of phosphates and-optionally—of ribose must precede any biological activity.

Enzymes with wide substrate specificities, such as $5^{\prime}$-nucleotidase, or alkaline and acid phosphatases, were thought to dephosphorylate the nucleotides. Additionally, the enzymes of the nucleotide salvage pathway may be of importance to CK metabolism (as reviewed by Chen [135]).

A CK-specific phosphoribohydrolase has been identified in rice [136]. A mutant of the corresponding gene in rice was identified based on a screen for plants with defects in the shoot meristem. Flowers of this particular mutant often contained only one stamen and no pistil. Hence, it was called lonely guy $(\log )$. Because of a clustering of LOG homologues in Agrobacterium rhizogenes and Rhodococcus fascians to IPT genes, its involvement in CK metabolism was elaborated. Indeed, it was shown to activate the CK nucleotide monophosphates in one step. None of the following underwent conversion: CK di- or triphosphates, AMP, CK nucleosides, or free bases [136]. Similar results were obtained with LOG from the pathogenic fungus, Claviceps purpurea; although, low activity with AMP was reported [137]. Notably, the activity with AMP was higher than with di- and triphosphates of CKs. Bacterial LOGs [138-141], as well as Archeal LOG [142], were shown to hydrolyse AMP. Their activity towards CK nucleotides was not estimated in vitro, with the exception of the Mycobacterial enzyme.

Notably, no IPT genes were identified in the genomes of Archaea [143] and so they are not expected to contain any CKs. Thus, the function of the LOG-like proteins in Archaea may be sensing and/or deactivation rather than activation of signalling compounds, in this case possibly cyclic di- and linear oligo-nucleotides [144]. 
The rice and Arabidopsis genomes contain 11 and 9 LOG genes, respectively [25,136]. The Arabidopsis proteins in general do not discriminate much between respective nucleotide monophosphates of isoprenoid CKs. Activity with BAPRMP ranged approximately from $5 \%$ to $75 \%$ of the activity relative to that with iPRMP [25]. Upon LOG overexpression, plants showed increased levels of iP, iP7G, and iP9G; decreased levels of iPRMP; and levels of iPR remained the same.

AtLOG7 possesses a central role in the CK activation, as knockout of only this one gene led to pronounced alterations of $\mathrm{CK}$ metabolism. By contrast, multiple knockout lacking all AtLOGs but AtLOG6, AtLOG7, and AtLOG9 (the authors of the study did not create mutants of AtLOG6 and AtLOG9) had CK levels comparable to WT plants [145]. Remarkably, AtLOG7 is the only protein with slightly higher activity than the rice LOG protein, with the rest of the proteins having much lower activity. Additionally, AtLOG7 has the most consistent activity towards all isoprenoid CKs, but its expression is rather low [25]. Following an opposite pattern, the most highly expressed gene is AtLOG8, but the corresponding enzyme has the lowest activity [25]. Thus, AtLOG7 and AtLOG8 are other examples that follow the criteria of Hulk and Deadpool, respectively.

In exceptional cases, enzymes of CK metabolism can occur as chimeras. A fusion protein of isopentenyltransferase and Lonely guy was discovered in Rhodococcus fascians [146], Claviceps purpurea [137], Fusarium pseudograminearum [82], and several other Fusarium species [147]. Most species of the Fusarium fujikuroi species complex have two genes coding for such a fused protein. Fusarium proliferatum ET1 has even three IPT-LOG genes [147]. Furthermore, all of the fungal fusion genes are clustered with a cytochrome P450. C $p$ IPTLOG was able to perform both activities and it showed higher preference for DMAPP over HMBDP. Notably, ADP and ATP did not serve as substrates [137].

These organisms with IPT-LOG fusion proteins are all pathogens that utilise Hulk CKs to inundate their host with active CKs to override the tightly balanced production of CKs normally required by plants. Thus, it is advantageous for the pathogens to link the production of CKs with their activation, which is unlike the need for plants to more strictly regulate the spatio-temporal distribution of both activities.

Although LOG may provide the most straightforward option for CK activation, there is some circumstantial evidence indicating there is a significant occurrence of the two-step activation. First, there are considerable amounts of ribosides in planta, often at similar, if not higher, levels than those of the nucleotides (e.g., $[19,49,81]$ ). If LOG activation was the main option, the ribosides would be expected to be present in only minute quantities and the nucleotides would be the major forms among the active trinity of nucleobases, nucleosides, and nucleotides. Second, the ribosides are considered to be the main transport forms of CKs $[148,149]$. The CKs could be dephosphorylated before xylem loading and phosphorylated upon unloading from xylem sap by nonspecific phosphatases/kinases. This would ensure an effective distinction between the translocation and local forms of CKs, which is analogous to sugar transport via sucrose as the transport form. Considering that grafted WT roots are not able to rescue the phenotypes of $\log$ shoots [113], it appears that, if riboside is truly the main translocation form, indeed, the unloading must be coupled to phosphorylation followed by dephosphoribosylation at the place of action. Further, Osugi et al. [149] ascribe the restoration of $t Z$ in the shoots of $\log / \mathrm{WT}$ grafted plants to direct root-to-shoot $t Z$ transport. Alternatively, it could be activated, at least partly, through the two-step process upon $t Z R$ transport. Third, knocking-out $L O G$ genes does not diminish the levels of CK free bases (e.g., $[145,150,151])$. On the contrary, plants with altered expression levels of the enzymes from the two-step pathway have altered levels of CKs [152,153]. Lastly, CKs fed to plants are often ribosylated and/or phosphorylated [34,73,145]. Thus, at least in some instances, the CKs are interconverted by way of the nucleoside form.

Although the enzymes of the two-step activation pathway often prefer adenine-type molecules as substrates, there are certain exceptions [154,155]. Moreover, while LOGs have a $K_{M}$ higher than $5 \mu \mathrm{M}[25,136]$, the enzymes of the two-step activation pathway may prefer Ade-type compounds, but their $K_{M}$ for CKs is typically lower than $5 \mu \mathrm{M}$ (e.g., [154-157]). 
This would mean that these enzymes are quickly saturated and work slowly but steadily providing a Deadpool signal. On the other hand, the LOGs are more responsive to the changes of CK concentrations and thus may better respond to the surge of Hulk signal.

Considering that all of the enzymes of the salvage pathway may operate in both directions if provided with appropriate substrates, there is another possibility. The enzymes may in fact operate in the direction of free base $->$ riboside $->$ ribotide and serve as a deactivation pathway, as has been shown for the CK riboside phosphorylase [155].

Nevertheless, even when LOG does activate the CKs, hydrolysis of $\beta$ - and $\gamma$-phosphates must occur first, as ADP and ATP are the preferred substrates of plant adenylate ITPs (e.g., $[158,159])$. It was reported that in some organisms, LOGs are organised in operons or as fusions with certain phosphoanhydrases or Nudix hydrolases [138]. Proteins coded by these genes could be responsible for the hydrolysis of CK nucleotides.

\section{Deactivation of Cytokinins}

There are several options for CK deactivation, when they are present at higher quantities than needed. The first option is ribosylation, which can be followed by phosphorylation $[34,73,145]$. The other option is glycosylation at the side chain of zeatins and topolins or on the adenine ring. The final known option is irreversible degradation by CKX. Alternatively, they may be transported to another cell compartment.

While conjugation of auxin, jasmonic acid, and salicylic acid with amino acids is well established, the formation of CK conjugates with amino acids is an unspoken secret in the CK community. However, unlike the other phytohormones that form expectable amides, CKs bind alanine and homoalanine unusually through the terminal carbon of their side chain to the adenine's endocyclic nitrogen to form lupinic acid and discadenine, respectively (Figure 4).<smiles>CC(C)=CCNc1ncn(CCC(N)C(=O)O)c2ncnc1-2</smiles><smiles>C/C(=C\CNc1ncnc2c1ncn2CC(N)C(=O)O)CO</smiles>

Figure 4. Structures of the only known cytokinin-amino acid conjugates: discadenine (left) and lupinic acid (right).

Lupinic acid (and analogous dihydrolupinic acid) was reported in the 1970s and 1980s as a product of (dihydro)zeatin (riboside) feeding to explants or calli of the Fabaceae family (e.g., [160-162]) or to immature lupin or apple seeds [163]. An analogous compound was formed when BAP was fed to the plants $[164,165]$ and the enzyme used a wide range of compounds with iP being the best substrate [166]. However, it has not been reported since that time and, thus, it is not clear how widespread this enzymatic activity is, the importance of this pathway, and whether there are other analogous compounds in planta.

On the other hand, discadenine was identified as a sporulation inhibitor in the amoeba Dictyostelium discoideum. It was shown to exert CK activity in tobacco callus bioassay and modest activity also in Amaranthus bioassay [167,168], but it did not affect the growth of Dictyostelium [169]. 
Possibly, Claviceps purpurea may also utilise a similarly specialised compound as the mutant in the CYP450 gene showed much higher sporulation rates [137]. Although both organisms belong to different supergroups [170], it would be possible that they both use a similar mechanism for sporulation regulation involving a CK derivative.

\subsection{Glycosylation}

CKs can be glycosylated either at the nitrogens of the purine ring or at the hydroxyl of the side chain of zeatins or topolins. Many conjugates of CKs have been identified in the past. Besides the canonical glucosides and ribosides, there are also $O$-xylosylderivatives of (dihydro)zeatin [171], CK ribosides with a glucose attached to ribose [172,173], or zeatin riboside with a branched 5-sugar chain on the side chain [174]. One could include also O-acetyl-(dihydro)zeatin identified in yellow lupine [175], although this is an ester and not a glycoside. Nevertheless, the significance of these modifications is challenging to estimate as there have been no follow-up studies.

Glycosylation of CKs on the side chain leads to a loss of activity, because the modified side chain can no longer be recognised by receptors. The $O$-glucosylation is thought to be reversible, since $\beta$-glucosidase from maize is capable of hydrolysing CK O-glucosides [176] and the glucosides can thus operate as a storage form [177]. However, it is their subcellular localisation that determines their fate. It has been noted for decades that plants accumulate $O$-glucosides in mature or senescing leaves [178]. As exogenous $O$-glucosides possess antisenescence activity (e.g., [179]), a strict compartmentation in plant cells was proposed. The $O$-glucosides were shown to be present predominantly in the apoplast and to a lesser extent in vacuoles [180,181]. Additionally, they were reported in chloroplasts after prolonged darkness [182,183]. In the apoplast, they probably originate from deactivation to prevent further activation of the receptors, and in vacuoles, they are stored until being degraded or re-used. Possibly, vacuolar CKXs physically interact with yet unknown glucosidases to prevent leakage of CKs to cytosol during degradation of CK O-glucosides. It is noteworthy though that the majority of the O-glucosides is in the apoplast [181].

Targeting maize $\beta$-glucosidase to vacuoles led to decreased accumulation of $t Z O G$ in tobacco grown on medium with $t Z$, while localisation to chloroplast (its natural compartment) increased it [184]. Hence, O-glucosides localised in vacuole are usually not hydrolysed, and targeting $\beta$-glucosidase to this compartment depletes these pools, and other means of deactivation must be found. On the other hand, localising it to plastids leads to increased turnover of CKs and their release into other compartments until they are terminally inactivated in a vacuole.

It has been suggested that the $O$-glucosides are transported both into chloroplasts and vacuoles as conjugates [184]. However, a more parsimonious explanation would hold that CKs are synthesised in the chloroplast [23], where the O-glucosylation occurs at night [182] when active CKs are not required. Hence, the CK O-glucosides serve as storage forms in the chloroplast. When the CKs are required, they are hydrolysed by a $\beta$-glucosidase and transported into the subcellular compartment as needed. Once no longer required, they are glucosylated and transported into the vacuole, where they are stored as inactivation products. Whether they are first glucosylated and then transported into the vacuole or vice versa is currently not possible to confirm, but there are no known transporters of CK glucosides. On the other hand, no known CK glucosylating enzymes were reported to localise to the vacuole either. However, neither were they reported to localise to chloroplasts where the $O$-glucosylation occurs.

A modification of the adenine ring diminishes binding to CK receptors [58], but enzymes of CK metabolism, notably the catabolic CKX [18,19], and possibly also the transporters, may still recognise these metabolites. Thus, the $\mathrm{N}$-glucosides are considered the deactivation products. However, the ability to $\mathrm{N}$-glucosylate $\mathrm{CKs}$ was clearly gained later during evolution as cyanobacteria, algae, and bryophytes generally contain low to null amounts of CK $N$-glucosides (cf. [27,51,52]). The question, however, remains: why have plants evolved another system for CK deactivation if it were terminal, when another system 
works perfectly well? The glucosylation is rather a Deadpool form of inactivation as it operates already at low disturbances of CK levels, when the Hulk deactivation by CKX is not necessary (see, e.g., [21]). Intriguingly, the ability to glucosylate CKs may have evolved to eliminate the need for degradation by CKX, which produces toxic aldehyde, as has been observed for Mycobacterium [138].

Cytokinin $\mathrm{N}$-glucosides were sometimes reported as active CKs at the beginnings of CK research (e.g., $[179,185,186]$. In some cases, their activity was even higher than that of the corresponding free base. However, once they have been shown not to bind to CK receptors [58], they were re-branded as inactive compounds. However, recent research suggests that $\mathrm{N}$-glucosides indeed show activity in certain bioassays $[17,187]$. The activity seems to be limited to anti-senescence effects, though (Figure 5). It is actually known for a long time that structural requirements to affect processes not involving growth are laxer [7]. Moreover, targeting the CKX into the vacuole, which contains predominantly $\mathrm{N}$-glucosides [181], leads to a typical CK-deficient phenotype [188,189]. This suggests that vacuole-stored CKs are still important for the plant.

There are several possible modes of action of $\mathrm{CK} N$-glucosides:

I. They are active per se through:

a. Binding to $\mathrm{CK}$ receptors-currently, $\mathrm{N}$-glucosides were shown not to bind to $\mathrm{CK}$ receptors, but the reported specificities may not reflect situations in planta as could be illustrated by potent CKs DHZ or BAP, which are often reported with dissociation constants one-to-two orders of magnitude higher than $t Z$ or iP (e.g., $[13,58,68,70,190])$.

b. Binding to other receptors or binding proteins- $\mathrm{CKs}$ and their derivatives are known to bind various proteins, including cyclin-dependent kinases or CK binding protein [191].

c. Alteration of CK metabolism, e.g., by inhibition of CKX or conjugation enzymes, which would prevent $\mathrm{CK}$ inactivation and thus increase the concentration of active CKs. This mode of action could work also in the case of the abovementioned BAP and DHZ to explain the discrepancy with the affinity of CK receptors and their biological activity.

II. Hydrolysis to free bases, which in turn exert the activity; however, this would not explain the differential regulation of gene expression upon treatment with free base, N7- or N9-glucoside [187]

The $N$-glucosides are usually referred to as resistant to hydrolysis, but there are several reports of their hydrolysis. For example, kinetin N3-glucoside is cleaved by $\beta$-glucosidase (other N3-glucosides were not tested; [176]) and activity of DHZ3G in bioassays is also attributed to hydrolysis [192]. Further, tobacco cells converted BAP7G to a nucleotide, hence hydrolysis of the glucose had to have occurred [193]. Similarly, WT tobacco leaf discs hydrolysed BAP3G and BAP9G but not DHZ7G or DHZ9G [194]. Additionally, free BAP is released in soybean from its N9-tetrahydropyrrol and N9-tetrahydrofuran derivatives [195] and N9-tetrahydropyrrol and N9-glucosides of 3-methoxyBAP, BAP, and DHZ are hydrolysed in maize but not in Arabidopsis [75]. Recently, tZ7G and $t Z 9 G$ were shown to be hydrolysed in Arabidopsis seedlings and a cell line, while no hydrolysis of iP7G, iP9G, or cZ9G was observed [196]. However, concentrations of most metabolites remained about the same for the first 100 min of treatment. Hydrolysis of $t Z 9 G$ in oat leaf segments or in excised Arabidopsis cotyledons was not observed (Hluska, unpublished results). The notion of resistance of $\mathrm{N}$-glucosides to hydrolysis comes from work on a sole enzyme [176], but it is possible that other hydrolases exist that can release active CKs from their conjugates. 

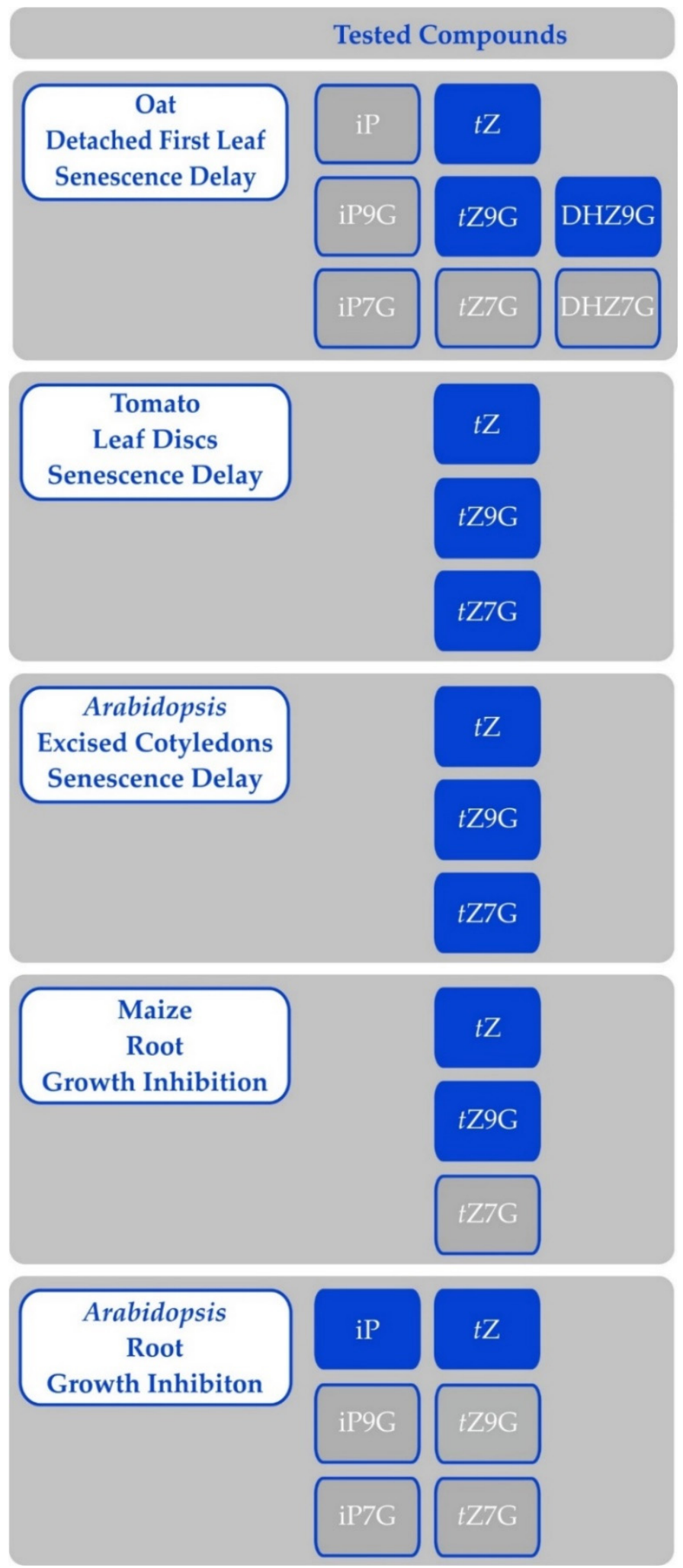

Figure 5. Activity of cytokinin free bases and $N$-glucosides in various bioassays; results of Eva Pokorná and Václav Motyka. Compounds on blue background were active in the specified bioassay, while compounds on grey background were inactive. Any compounds not listed in either column were not tested. 
The first described enzyme glucosylating CKs was a cytokinin 7-glucosyltransferase from radish cotyledons [197]. It could use a wide range of substances, including adenine or aromatic CKs. Among them, compounds with a saturated side chain were preferred.

An interesting comparison for the study of CK glycosylation came from the common bean (Phaseolus vulgaris) and lima bean (Phaseolus lunatus). These species are related, yet they differ in their ability to glycosylate CKs and possibly also to degrade them (as hypothesised by Mok et al. [30]). The xylosyltransferase (tZOXT) from Phaseolus vulgaris uses exclusively UDP-xylose, while the glucosyltransferase (tZOGT) from Phaseolus lunatus is able to use both UDP-glucose and UDP-xylose [171,198]. Meanwhile, the $t Z O G T$ was specific for $t Z$, while the $t Z O X T$ could utilise both $t Z$ and DHZ. Neither $c Z$, nor $t Z R$ were substrates for either of the enzymes. The genes were later identified $[199,200]$.

While both cytokinin $O$-glucosyltransferases identified in maize have strict specificity for cis-zeatin and were thus designated as cis-zeatin O-glucosyltransferases (cZOGT; [42,57]) with only weak activity towards $t Z$ [42], there are five CK-specific glucosyltransferases in Arabidopsis [201] and they do not strictly discriminate between the zeatin isomers. Of these, two produced $\mathrm{N}$-glucosides with preference for N7-glucoside, and showed no discrimination of substrates with the exception of BAP. The other three enzymes produced $O$-glucosides, but two of them had very low activity. They were reported later to utilise other substrates [202,203]. However, UGT85A1 glucosylates $t Z$ and $c Z$ with similar activity, while DHZ was the least effective substrate.

It should be noted though that the five Arabidopsis enzymes were identified in a screen of 105 glucosyltransferases for their ability to glucosylate five CKs, which did not include cis-zeatin. Thus, it is possible that other glycosyltransferases, using other sugar donors and/or cis-zeatin as an acceptor, exist in Arabidopsis. Furthermore, there was no genome or "glucosyltransferase-ome"-wide search for CK-specific enzymes in maize. Therefore, it is still possible other CK-specific glycosyltransferases are present in maize.

With all of this considered, the differences in preference of $O$-glucosyltransferases in these model organisms for $c Z$-type- and $t Z$-type-dominant species led to the proposal of a novel hypothesis explaining the prevalence of isomers of zeatins in each of them [81]. Rather than a selective drive towards the preference for one isomer over the other, the substrate specificity of the $O$-glucosyltransferases seems to have resulted in a random drift towards a predominance of one isomer or the other. A kingdom-wide analysis of CKs [27] showed that preference for one zeatin isomer or another is not restricted to a particular taxon but is in fact a random occurrence. This is compatible with a single locus being solely responsible for this divergence rather than a complex network that would require more mutations to switch from one isomer system to the other. Furthermore, expression of $t Z O G T$ in maize was observed to lead to equal amounts of $c Z$-type and tZ-type CKs in mature plants [204], thereby confirming, once again, that the selectivity of $O$-glucosyltransferases may be responsible for the prevalence of either one of the isomers.

The existence of $c Z$-type-dominant plants would suggest that $c Z$ may function as Hulk CK in certain species, especially as it exerts a similar activity in bioassays employing such plants $[38,46]$. However, this hypothesis suggests that even these plants are not capable of fast and inducible $c Z$ production and thus it probably acts as a Deadpool even in these plants. Nevertheless, more testing would be required to dissect this question.

Recently, two CK-specific glucosyltransferases putatively forming O-glucosides were suggested to be involved in ovule development through regulation by CUP-SHAPED COTYLEDON1 (CUC1) and 2 [205]. However, the authors identified UGT85A3 and UGT73C1 as the enzymes linking CUC transcription factors and CK metabolism, although the first one was shown to lack activity towards CKs [201] and the second exerts much higher activity towards TNT derivatives [202]. Further, the authors reported a decrease of $\mathrm{CK}$ free bases and an increase of CK glucosides in knockdown plants. Yet, the biggest decrease is observed for iP, which cannot form O-glucosides. Additionally, there is a much bigger increase of $\mathrm{CK} \mathrm{N}$-glucosides in contrast to $\mathrm{CK}$ ribosides $\mathrm{O}$-glucosides. Last, there was no direct data to indicate that these enzymes indeed glucosylate CKs. Plants 
with altered levels of these UGTs had a similar phenotype as the plants with altered CUC expression. This was expectable as the UGTs were deregulated in such plants. Nonetheless, the authors have not determined the CK content in plants with altered UGT expression or in vitro activity of these enzymes.

Rice and maize, both $c$ Z-type-dominant plants, were transformed with cZOGT and tZOGT $[38,204,206]$. Predictably, the plants had increased levels correspondingly of mainly $c Z(\mathrm{R}) \mathrm{OG}$ and $t Z \mathrm{OG}$. Both species had reduced shoot growth (a CK-deficient phenotype). With the exception of Shang et al., the authors unexpectedly also observed elevated levels of chlorophyll and delayed senescence, which are traits usually associated with high CK levels [207]. Indeed, the maize plants showed increased levels of $t Z$ and iP in the leaves. Additionally, roots were longer, although rice had a reduced number of crown roots $[38,206]$. Thus, in general, the phenotypes were similar. The only notable difference was the development of sexual organs and seeds, which was highly affected in the maize expressing tZOGT [204]. Mainly the size of tassels was reduced by $75 \%$ in heterozygous plants and they were feminised to varying degrees in homozygous plants [204].

\subsection{Cytokinin Oxidase/Dehydrogenase}

The enzyme that degrades CKs is one of the longest studied of those involved in CK metabolism and it is, thus, the best characterised one. The topic of CK degradation has been reviewed extensively by others [208,209].

The enzyme was first described in the 1970s [210] and cloned independently by two groups almost 30 years later [211,212]. It is a flavoenzyme with covalently bound FAD using artificial electron acceptors [213]. Putative natural electron acceptors were identified [214]. Because the enzymes efficiently use $Q_{0}$, an isoprenoid side chain-deprived analogue of ubiquinone, it was proposed that the cytokinin oxidase/dehydrogenase enzymes may be associated with membranes [213]. Recently, AtCKX1 was shown to be a transmembrane protein localised to the endoplasmic reticulum (ER; [215]).

CKXs form small gene families. The respective enzymes differ in subcellular localisation, temporal and spatial expression, and substrate preferences. The most studied are enzymes from Arabidopsis and maize. Several genes were cloned and heterologously expressed [132,211,212,216-218]. Characterisation of the complete family of CKX enzymes was performed in Arabidopsis and maize [18,19].

The CKX expression and/or activity is usually induced upon CK application [219-222]. It was suggested that CKX may play a role of a "detoxifier" [221]. However, in few exceptions, higher CK content led to decreased expression of (some) CKX genes (e.g., [21,43,223,224]). This may result from various needs for particular isoforms due to their substrate specificities and/or subcellular compartmentalisation.

CKX is able to efficiently degrade all types of natural CKs, with the exception of resistant DHZ $[18,19]$ or aromatic CKs that are very weak substrates [18,218]. Additionally, $c Z$ was considered as a weak substrate, but there are several enzymes that cleave it preferentially. Among them, $Z m C K X 8,9$ and 10 [19] or AtCKX1 and 7 [27]. Indeed, Arabidopsis overexpressing $A t C K X 1$ or $A t C K X 7$ had drastically reduced levels of $c Z$-type CKs [55]. Considering that AtCKX7 and ZmCKX10 are the only CKX from the respective organisms localised to cytosol, the preference for $c Z$-type CKs may not be a coincidence as they may be involved in removal of the cytosol-localised Deadpool tRNA-derived $c Z$.

The effect of CKX on important agricultural traits has been known at least since the iconic identification of OsCKX2 as the determinant of grain yields in rice [225]. Similar results were observed in other works [226-229] for which lower CKX expression led to more tillering, an increased number of siliques and/or seeds, and thus to higher yield. Interestingly, Zhang et al. [230] observed a positive correlation between the grain number per spike and the expression of two $T a C K X 2$ genes in young spikes. These genes are the most similar to OsCKX2 and AtCKX3 described in the other studies, the expression of which correlates negatively with these agricultural traits. 
Constitutive expression of $C K X$ leads to stunted shoot as was shown in the influential work by Werner et al. [56] as well as in other works (e.g., [231]). Thus, the reduction of CK levels by means of $C K X$ root-specific overexpression became a well-defined approach to crop improvement. It leads to increased root systems both in the model plants Arabidopsis and tobacco [232] as well as in agricultural plants, such as barley [189,233], rice [234], and poplar [235]. This leads to better dealing with drought stress [189,232,233] and/or improved mineral uptake [232,233,236].

An interesting tactic would be to combine both approaches, i.e., upregulation of $C K X$ expression in the roots and downregulation of the CKX expression in the shoots and/or grains, and observe whether this leads to synergistic strengthening of the sink in the seeds and further enlargement of yield, possibly also with improved mineral content as has been observed for other combinations of traits [237].

The involvement of CKX influence on agricultural traits was recently reviewed in more depth in an excellent review by Chen et al. [238].

\section{Cytokinin Signalling}

The transduction of a CK signal relies on a modular system similar to that used by bacteria known as two-component signalling, which reflects that it is composed of hybrid histidine kinase (HK or CHK for CHASE-domain containing histidine kinase; see Heyl et al. [239]) receptor and response regulator (RR). In plants, an additional component is required - a histidine-containing phosphotransfer protein (HPT) - for transfer of the signal to the nucleus (Figure 6). The CK signal circuitry was reviewed in more detail recently $[12,240]$.

There are three CK receptors in Arabidopsis. The CK receptors contain a CHASE domain at the N-terminus surrounded by two or more transmembrane helices. The CHASE domain was reported to contain two PAS(-like) domains [241,242]. However, the true PAS domains are present only in the cytosol and the extracytosolic PAS domains were assigned to a distinct Cache superfamily [243]. Thus, the CK receptors contain CHASE domains (without any subdomains) newly assigned to the Cache superfamily. The recently described cytokinin-sensing histidine kinase from Xanthomonas also contains two true intracytosolic PAS domains in addition to the CHASE domain [244].

Among the Arabidopsis CK receptors, AHK4 is unique: it is highly specific for free bases of $t Z$ and $\mathrm{iP}$ [58] and it possesses phosphatase activity in the. absence of CKs [245]. The AHK3 and the maize receptors also generally recognise $c Z$, and DHZ (and their respective ribosides) with affinities similar to those of other isoprenoid CKs $[58,59,69,70]$. A somewhat opposite situation was observed in an apple tree for which MdCHK2 (a homologue of AHK2) showed the widest substrate acceptance and highest sensitivity at the same time [14]. Interestingly, it is also the most highly expressed gene.

Potato CK receptors also showed partial differences in CK preferences in comparison with AHKs [190]. Notably, the potato receptors did not perceive $c Z$ with high activity, although it is present in potato at higher concentrations than the trans-isomer [33-36]. This would add to the abovementioned discrepancy of CK receptors not perceiving what are thought to be active CKs.

There is discrepancy concerning the subcellular localisation of the CK receptors. The first reports stated in 2011 that cytokinin receptors may not be present mainly on the plasma membrane [246,247]. Since this time, there were more reports supporting this opinion as reviewed by the authors of those papers [248], changing the view from endocycling to strictly functioning on ER. A favourite argument is the $\mathrm{pH}$ optimum of the receptors in a neutral-to-mildly basic range, which should correspond to ER lumen rather than apoplast (e.g., [13,190,249]). However, the apoplastic pH lies mostly in the range 5.0-6.5 [250], which is the range where the receptors change their activity. Thus, operating in this region provides another level that is subject to regulation. Indeed, the $\mathrm{pH}$ of apoplast is known to change in response to various cues [251]. For example, nitrate, known to induce shoot growth through action of the Hulk CKs $[24,113,114]$, increases the apoplastic pH above 
6.0 [252], where the receptors reach their maximum binding capacity. Originally, it was also suggested that this responsiveness to $\mathrm{pH}$ change may contribute to auxin-CK crosstalk [70] as auxin decreases $\mathrm{pH}$ in the apoplast. Recently, it was suggested that the ability of the receptors to form dimers is also $\mathrm{pH}$ dependent [249]. However, if we accept the premise that the $\mathrm{pH}$ of the apoplast is changing, that would also be irrelevant. Further, it is AHK3 that responds strongly to $\mathrm{pH}$ change [13] and it is localised to a lesser extent on the plasma membrane $[247,253]$ as compared to AHK4, which does not respond so strongly to the $\mathrm{pH}$ change. The poplar homologues of AHK4 showed, in fact, a negative correlation between tZ binding and $\mathrm{pH}$ [254].

Moreover, recent experiments confirmed that functional receptors are localised on the plasma membrane [253,255]. While Antoniadi et al. [253] showed that extracellular CKs are capable of CK receptor activation, Zürcher et al. [255] showed the significance of CK removal from the apoplast for proper development. Indeed, there are several apoplastlocalised CKX enzymes (e.g., [132,256]). However, this does not preclude additional localisation of the receptors to the ER. Expression of an ER-targeted anti-CK antibody led to developmental abnormalities [257]. Similarly, the AtCKX1 was shown to localise to the ER [215]. A higher proportion of AHK4 was reported to localise to non-ER membranes though [247,253]. Interestingly, perception of the extracellular CKs was most impaired in plants lacking AHK4, even in a single mutant [253]. Moreover, Kubiasová et al. [258] showed that the subcellular distribution of AHK4 varies in different cell types with actively dividing cells containing AHK4 on the plasma membrane. Further, CKs were shown to regulate endocytosis of several proteins $[259,260]$. This would be an additional negative feedback loop in CK signalling by the removal of the receptors. Thus, the AHK4 on the plasma membrane, recognising mainly $t Z$ and iP free bases, may perceive long-range Hulk signals in the vasculature with strong effects on the overall plant architecture. By contrast, the majority of AHK2 and AHK3 on the inner membranes perceive a wider range of $\mathrm{CKs}$, including $c Z$, originating from tRNA hydrolysis, serving also as the local autocrine Deadpool signal.

In conclusion, there are in planta experiments showing localisation of functional receptors on the plasma membrane. Although the experiments of Zürcher et al. [255] could not have differentiated between $\mathrm{CK}$ receptors functioning on the plasma membrane and those working on the endomembranes, if endocytosis was operational, it was shown that only a negligible fraction of the immobilised CKs goes inside cells [253]. Moreover, the point made about the receptors' binding capacity responding to $\mathrm{pH}$ is in fact an argument for the receptors' operation on the plasma membrane. However, as has been mentioned above, regulation of the CK levels in the ER is also crucial for proper plant development. Thus, likely, in the spirit of the original reports [246,247], CK receptors are functional on both membranes.

Another matter of dispute pertains to the ability of CK receptors to bind CK ribosides. Those were traditionally grouped with free bases, and classified as active forms because of their activities in various bioassays. Indeed, the original measurements with CK receptors in the heterologous E. coli system confirmed their binding [58,59]. It was suggested later that only eukaryotic membranes should be used to evaluate CK receptors' binding properties [13]. The authors concluded that ribosides are not bound by the receptors. Although not entirely clear from the presentation, the data seem to suggest that at least $Z m \mathrm{HK} 1$ binds $\mathrm{iPR}$ with a dissociation constant one and two orders of magnitude larger than $t Z$ and $c Z$ or iP, respectively. This is about three times lower than the dissociation constant for the binding of DHZ. However, the authors did not measure activation of the signalling cascade, which may have been prevented by sterical hindrance. Nevertheless, Daudu et al. observed the growth of yeast expressing apple tree $\mathrm{MdCHK} 2$ on $\mathrm{CK}$ ribosides at concentrations at least 100-times higher than of free bases [14]. Notably, those authors also observed growth on $t Z O G$ at the same concentration as on $\mathrm{PPR}$. 

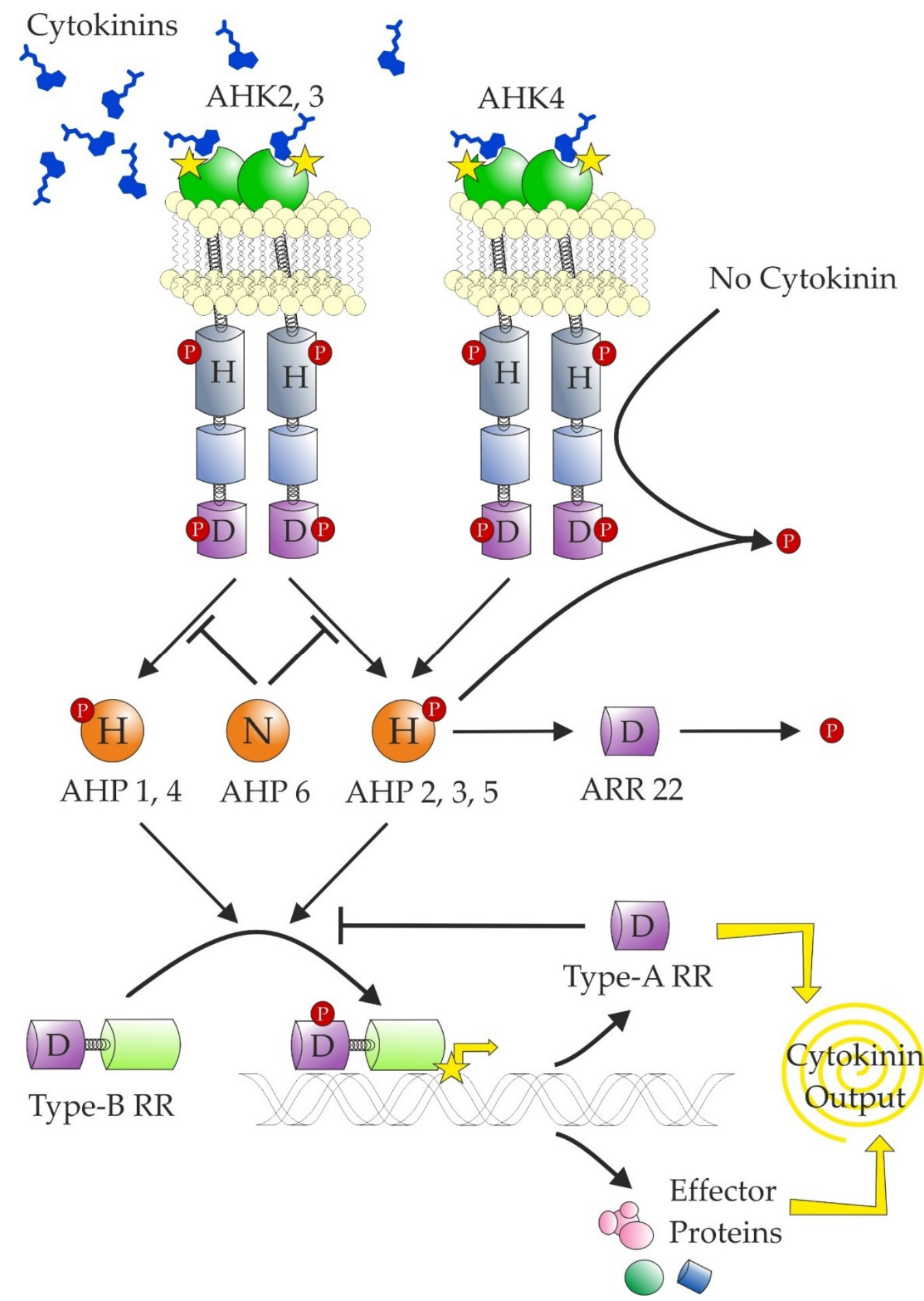

Figure 6. Schematic representation of current knowledge of cytokinin signalling. The transmembrane cytokinin receptors (histidine kinases) auto-phosphorylate in the presence of cytokinins and subsequently transfer the phosphate to the histidine phosphotransfer proteins (AHPs). However, in the absence of cytokinins, AHK4 has phosphatase activity and dephosphorylates all AHPs. The transfer is inhibited by AHP6, which has a substitution of the conserved Asp for Asn. $\mathrm{AHP} 2,3$ and 5 are rapidly dephosphorylated by ARR22. The AHPs transfer the phosphate group to type-B response regulators, which work as transcription factors. One of their targets are type-A response regulators, which inhibit the phosphotransfer from AHPs to type-B RRs. The conserved residues are marked (H—histidine; D—aspartate; $\mathrm{N}$-asparagine). The phosphate group is marked by a P contained in a red circle. The extracytosolic CHASE domains are shown in green, kinase domains are shown in grey, and receiver and receiver-like domains are respectively shown in violet (marked with a D) and light blue (no D). 
Upon CK binding, the receptors putatively form dimers and transfer phosphate to HPTs. Such dimerisation was observed several times (e.g., $[14,246,247,261,262])$. Noteworthy, studies that used BiFC did not include proper negative controls [263]. Indeed, such studies detected all tested interactions. In other instances, often heterodimerisation is observed, while formation of homodimers is not. Yet, the heterodimerisation does not seem to be physiologically relevant [264]. This begs the question of whether the observed interactions reflect true contact or an artefact. Moreover, the putative inability to form homodimers contradicts the ability to detect activation of two-component signalling in heterologous systems where only a single receptor is expressed.

Recently, CK signalling was elucidated in bacteria [244,265]. The receptor from Xanthomonas campestris pv. campestris specifically binds iP. Rather than activating the phosphorylation cascade, this binding lowers the phosphate load in the system, ultimately leading to hydrolysis of 3',5'-cyclic diguanylic acid [244]. In the human pathogen Mycobacterium tuberculosis, CK induces the formation of a lipid-like molecule, which binds to a repressor and de-represses the expression of a responsive gene. However, unlike canonical CK signalling, the Mycobacterium one is significantly inhibited by adenine [265].

Following phosphorylation, HPTs transfer the phosphate to downstream proteins in the nucleus [266]. However, it was shown that the localisation of HPTs is independent of CK perception [267]. Unlike the other HPTs, the Arabidopsis HPT6 has the conserved Asp replaced with Asn and thus cannot accept a phosphate. It competes with the other HPTs in binding to the receptors and thus attenuates the CK signalling [268].

Among the receiver proteins are Response Regulators, which are classified as type$A,-B$, and $-C$, based on their domain structure and responsiveness of their expression to CK treatment [269]. Type-B RRs are positive regulators of the CK response and they serve as transcription factors directly influencing the expression of response genes [270]. Additionally, type- $A$ RRs belong to the response genes [271] and serve as negative regulators of the CKs, probably by competing with type-B RRs for the phosphate. Thus, they serve as a negative feedback loop. The function of type-C RRs is less thoroughly characterised [12]. Their structure resembles that of type-A RRs, but on the amino acid level, they are more similar to the receiver domain of the receptors and their expression is not upregulated by CKs [272]. Spatially, their expression is restricted to reproductive organs [272,273].

Cytokinin Response Factors (CRFs) are land plant-specific members of the AP2/ERF protein family $[274,275]$. They are characterised by the CRF domain, single AP2/ERF domain, and CRF1-6 also contain the MAPK phosphorylation site motif [275]. CRF proteins form homo- and heterodimers and interact also with HPTs and rarely with response regulators. The CRF domain is solely responsible for the interaction [276]. However, only some of them are upregulated by CKs [277]. The CRFs were implicated in response to a range of abiotic stresses [278-284].

Lastly, GL1 ENHANCER BINDING PROTEIN (GeBP) and GeBP-like (GPL) transcription factors were implicated in CK signalling [285]. These unconventional leucine zippers form homo- and heterodimers, which localise to the nucleus. Triple mutant gebp gpl1 2 did not arrest its growth in the presence of kinetin unlike WT. In general, this mutant phenocopied the double mutant of type-B RRs. However, no further studies in relation to CKs have been reported.

\section{Cytokinin Transport}

Over the years, there have been several indirect lines of evidence for CK transport. CKs serve as a long-range signal for nitrogen $[24,286]$, and $t Z$ - and iP-type have been detected in xylem and phloem sap, respectively [40,148,286-289]; experiments with grafted plants have repeatedly shown the ability of WT roots or shoots to complement for a detrimental mutation $[120,290,291]$ and overall, the transport of CKs has been shown [175,178,292]. Lastly, the expression sites of IPT and LOG genes do not overlap with the CK response domains [12]. However, for a long time, the CK transporters had remained elusive. 
The first transporter family implied in CK transport were purine permeases (PUPs), with Arabidopsis thaliana purine permease 1 (AtPUP1) inhibited by kinetin and zeatin and to a lesser extent by their ribosides [293]. Later, direct transport of $t Z$ was shown [294]. Two rice orthologues were also implicated in grain development due to CK transport [295].

Other candidates for CK transport are the equilibrative nucleoside transporters (ENTs), which transport purine and pyrimidine nucleosides. As the name suggests, in principle, they are bidirectional, and the compound concentration determines the direction. However, circumstantially, the adenosine uptake is probably coupled with phosphorylation to trap the nucleoside intracellularly [296]. Several members of this family have been shown to be inhibited and/or to transport various CKs $[148,297,298]$. However, multiple members of the transporter family from Arabidopsis were previously characterised and reported not to transport kinetin, zeatin, or $t Z R$ [299]. The discrepancy could be due to the use of $t Z$-type CKs, which have much higher $K_{M}$, but Hirose et al. [148] showed a reduction of the adenosine uptake by $20-30 \%$ even with $t Z R$.

Nevertheless, because of the low affinities towards CKs and comparable or higher affinity of these transporters towards canonical nucleobases or nucleosides, their involvement in CK transport was often disputed [208,300]. Since then, a growing body of evidence has been showing direct involvement of various transporters with CKs in planta. By the means of a screen for the suppressor of IPT overexpression, AtENT8 was identified as a potential CK transporter [298].

Several members of the ATP-binding cassette transporter subfamily G, namely Arabidopsis AtABCG14 [301,302], rice OsABCG18 [303], and apple tree MdABCG28 and 70 [304], were recently shown to transport CKs. The first indicia was co-expression of AtABCG14 with AtIPTs and induction of its expression upon CK treatment [302]. All of them are mostly expressed in the roots and in the vasculature in general and their expression is upregulated by CKs. The transporters localise to the plasma membrane [301-303]. The knockout mutant phenotypes resembled other CK-deficient mutants [301-303]. Similarly, the expression of MdABCG28 was decreased in a dwarf line of apple tree [304]. The dwarf phenotype of shoots could be rescued by application of $t Z$ but not iP [302,303], while root elongation was less sensitive to $t Z$ application in the mutants than in WT plants [301]. The CK content in the mutant roots was higher, while it was lower in the shoots. Indeed, the expression of the response regulator genes corresponded accordingly [301,302]. Grafting experiments showed unequivocally that root-derived $t Z$ is crucial for the development of shoots but that shoots do not affect the growth of roots [302]. Later, AtABCG14 was implicated in long-range nitrogen signalling, confirming its role in CK root-to-shoot transport [305].

Recently, three non-intrinsic ABC proteins AtABCI19, 20, and 21 were suggested to negatively regulate $C K$ responses [306]. The proteins lack a transmembrane domain and are part of a large protein complex localised to ER. It was hypothesised that they work either as transporters of CKs on the ER or they regulate translocation of CK receptors from the plasma membrane as they interact with COPI responsible for retrograde transport [306].

AtPUP14 was shown to be a negative regulator of CK signalling [255]. The cotyledons of Arabidopsis heart-staged embryo do not transmit the CK signal, even though AHK4 is expressed there and the downstream signalling pathway is functional as shown by expression of CKI1 - a constitutively signalling HK. Interestingly, AtPUP14 was also expressed in the lateral root primordia, the formation of which is strongly inhibited by CKs [307]. Transport of $t Z$ by AtPUP14 was directly shown, and it was ATP dependent. Transport of radioactive $t Z$ was inhibited by free bases of other CKs but not by $t Z R$. Further, $C K$ signalling was diminished in mesophyll protoplast cells upon AtPUP14 expression or upon the presence of CKX enzyme in the "apoplast" but not in the cytosol of the cells [255]. This clearly illustrates the importance of matching the subcellular localisation of CKs and their receptors for triggering of the signals. Analogous results were observed in barley [189]. Localisation of $A t C K X 1$ to the apoplast was detrimental to plant development, while plants with AtCKX1 directed to vacuoles showed only a weak phenotype and any phenotype of plants with cytosolic AtCKX1 was miniscule. 
Hence, AtPUP14 shall work as a stop signal of the CK signalling by depleting apoplastic CKs and thus inhibiting perception by plasma membrane-localised receptors [255]. Even though the kinetic parameters of AtPUP14 were not determined, $K_{M}$ of the homologues is in the range of tens $\mu \mathrm{M}[293,294]$, while the $K_{D}$ of the receptors is in the range of nM (e.g., $[68,69])$. However, the same works also showed a strong dependence of PUP activity on $\mathrm{pH}$ with a maximum in the acidic range while null activity in the neutral-to-weaklybasic range, i.e., complementary to the receptors. Thus, PUPs are likely another level of regulation ensuring that CK signal is not perceived where it is not desired.

Recently, a novel transporter family was implicated in CK transport. The Arabidopsis genome contains two genes encoding Aza-guanine resistant transporters (AtAZG). Both of them were shown to transport adenine and $t Z$ with high affinity [308,309]. Although, neither of the loss-of-function mutants, atazg 1 or atazg2, were distinguishable from WT plants in their ability to transport both adenine and $t Z$ [308,309], the atazg 1 plants had longer primary roots and a higher density of lateral roots. Moreover, root explants from those mutants required a higher concentration of kinetin for shoot regeneration [309]. The authors also concluded that AtAZG1 functions as an active transporter while AtAZG2 acts as a diffusion facilitator [308]. Considering that the proteins are identical almost at the $50 \%$ level and share similarity at more than $75 \%$ [310], it would seem unlikely they would differ so much in their mode of action. Further work should be more attentive to details like normalisation of $\mathrm{pH}$, monitoring of quantities of expressed protein, usage of natural substrates rather than hypoxanthine, and exploring alternative explanations (e.g., both strains may lose similar amounts of hypoxanthine, but AtAZG1 may be faster or have higher affinity for its uptake).

AtAZG2 localises both to the plasma membrane and to the endoplasmic reticulum. It is expressed in cells surrounding lateral root primordia, and upon auxin treatment, its expression increases and is more widespread [308]. This is an interesting complementary expression domain to the one of AtPUP14.

Because the knowledge on particular CK transporter families is still rather spotty, it is currently difficult to judge the framing of particular transporters in the Hulks \& Deadpool hypothesis with the exception of ABCGs transporting the long-range Hulk $t Z$. It is questionable whether AtPUP14 discarding the Hulk $t Z$ signal shall be labelled as Hulk because of the strong effect, or Deadpool, because it contradicts the Hulk signal. However, it is probably safe to hypothesise that in the mutational studies, the Hulk transporters with strong effects in mutants were identified. On the other hand, members of the PUP and ENT families that were not studied so far may still transport CKs, but their activity and/or expression may be low and/or widespread and thus of little interest when studying a particular process.

\section{Conclusions}

In this review, we presented a novel hypothesis showing that the Cytokinin Universe is full of both (i) strong Hulks with high CK activity, metabolite conversion, and sensing power that drives fast growth spurts and (ii) immortal Deadpools sustaining basal survival, metabolites, enzymes, and sensing mechanisms with lower activity but a long-lasting effect.

Here, we reviewed the metabolism, signalling, and transport of the plant hormones CK. This demonstrates that the production levels, and different forms of CK can determine which of the two different Hulk/Deadpool strategies take place. It also highlights that beyond the quantities and forms of CKs, the ability to translocate CKs to where they are needed and the type of sensitivity of the signal transduction machinery can directly affect the Hulk/Deadpool tactics. We included some of the old knowledge, which is currently neglected, and would be worthy of further investigation as elucidation of the significance of these metabolites or enzymes may be shifting erudition in the Cytokinin Universe and have potential utilisation, e.g., in agriculture.

We attempted to show that the current CK research mostly focuses on the Hulks, such as in cases of iP and $t Z, A t I P T 3$, LOGs, etc. This is probably simply because it is easier 
to study the large effects of Hulk knock-down or knock-up rather than subtle changes caused by alterations of the Deadpools, which often require multiple knock-outs to observe any phenotype.

Moreover, the focus of current research on the $t Z$-dominant species, Arabidopsis, and the neglect of the more dated, and perhaps forgotten, early research has led to many asof-yet unanswered vital questions. Examples include the importance of such enzymes as zeatin reductase or zeatin $O$-xylosyltransferase, which without renewed and more detailed study cannot be adequately gauged. The recent re-discovery of "novel" CKs hints that there may be more diversity to CKs and their metabolic pathways than is currently reflected by the emerging research topics. We tried to pin-point such old/new topics to generate more deserved attention.

Of course, not every CK, enzyme, transporter, receptor, etc. may be filed clearly as Hulk or Deadpool. In fact, most of them may lay somewhere in between. However, by pointing out to the obvious Hulks and Deadpools, we have tried to alert that not only are the Hulks important for plant development, but that the Deadpools also hence deserve their fair share of attention.

Supplementary Materials: The following are available online at https:/ /www.mdpi.com/2218-273 X/11/2/209/s1, Table S1: List of CK abbreviations.

Author Contributions: T.H. conceived the idea and wrote the first draft of the review with subsequent input from all authors. All authors have read and agreed to the published version of the manuscript.

Funding: This work was partly supported by the Czech Science Foundation (Grant No. 19-12262S) and the Ministry of Education, Youth and Sports of Czech Republic (European Regional Development Fund-Project "Centre for Experimental Plant Biology" (No. CZ.02.1.01/0.0/0.0/16_019/0000738) to T.H. and from NSERC Discovery Grant No. RGPIN-05436 to R.J.N.E.

Acknowledgments: Authors are grateful to Václav Motyka for critical reading of the manuscript. The authors wish to thank the reviewers for their constructive remarks improving our manuscript.

Conflicts of Interest: The authors declare no conflict of interest.

\section{References}

1. Miller, C.O.; Skoog, F.; Von Saltza, M.H.; Strong, F.M. Kinetin, a Cell Division Factor from Deoxyribonucleic Acid. J. Am. Chem. Soc. 1955, 77, 1392. [CrossRef]

2. Shantz, E.M.; Steward, F.C. The Identification of Compound A from Coconut Milk as 1,3-Diphenylurea. J. Am. Chem. Soc. 1955, 77, 6351-6353. [CrossRef]

3. Jacobs, W.P. Plant Hormones; Cambridge University Press: Cambridge, UK, 1979; ISBN 978-0-521-22062-0.

4. Ge, L.; Yong, J.W.H.; Goh, N.K.; Chia, L.S.; Tan, S.N.; Ong, E.S. Identification of Kinetin and Kinetin Riboside in Coconut (Cocos Nucifera L.) Water Using a Combined Approach of Liquid Chromatography-Tandem Mass Spectrometry, High Performance Liquid Chromatography and Capillary Electrophoresis. J. Chromatogr. B Analyt. Technol. Biomed. Life Sci. 2005, 829, 26-34. [CrossRef] [PubMed]

5. Barciszewski, J.; Siboska, G.E.; Pedersen, B.O.; Clark, B.F.; Rattan, S.I. Evidence for the Presence of Kinetin in DNA and Cell Extracts. FEBS Lett. 1996, 393, 197-200. [CrossRef]

6. Letham, D.S. Zeatin, a Factor Inducing Cell Division Isolated from Zea Mays. Life Sci. 1963, 2, 569-573. [CrossRef]

7. Skoog, F.; Armstrong, D.J. Cytokinins. Ann. Rev. Plant Physiol. 1970, 21, 359-384. [CrossRef]

8. Pongs, O.; Reinwald, E. Function of Y in Codon-Anticodon Interaction of TRNA ${ }^{\text {Phe }}$. Biochem. Biophys. Res. Commun. 1973, 50, 357-363. [CrossRef]

9. Agris, P.F.; Vendeix, F.A.P.; Graham, W.D. TRNA's Wobble Decoding of the Genome: 40 Years of Modification. J. Mol. Biol. 2007, 366, 1-13. [CrossRef]

10. Persson, B.C.; Esberg, B.; Ólafsson, Ó.; Björk, G.R. Synthesis and Function of Isopentenyl Adenosine Derivatives in TRNA. Biochimie 1994, 76, 1152-1160. [CrossRef]

11. Schweizer, U.; Bohleber, S.; Fradejas-Villar, N. The Modified Base Isopentenyladenosine and Its Derivatives in TRNA. RNA Biol. 2017, 14, 1197-1208. [CrossRef]

12. Zürcher, E.; Müller, B. Cytokinin Synthesis, Signaling, and Function-Advances and New Insights. Int. Rev. Cell Mol. Biol. 2016, 324, 1-38. [CrossRef] [PubMed] 
13. Lomin, S.N.; Krivosheev, D.M.; Steklov, M.Y.; Arkhipov, D.V.; Osolodkin, D.I.; Schmülling, T.; Romanov, G.A. Plant Membrane Assays with Cytokinin Receptors Underpin the Unique Role of Free Cytokinin Bases as Biologically Active Ligands. J. Exp. Bot. 2015, 66, 1851-1863. [CrossRef] [PubMed]

14. Daudu, D.; Allion, E.; Liesecke, F.; Papon, N.; Courdavault, V.; Dugé de Bernonville, T.; Mélin, C.; Oudin, A.; Clastre, M.; Lanoue, A.; et al. CHASE-Containing Histidine Kinase Receptors in Apple Tree: From a Common Receptor Structure to Divergent Cytokinin Binding Properties and Specific Functions. Front. Plant Sci. 2017, 8, 1614. [CrossRef] [PubMed]

15. Kamínek, M.; Březinov, A.; Gaudinová, A.; Motyka, V.; Vaňková, R.; Zažímalová, E. Purine Cytokinins: A Proposal of Abbreviations. Plant Growth Regul. 2000, 32, 253-256. [CrossRef]

16. Mik, V.; Szüčová, L.; Spíchal, L.; Plíhal, O.; Nisler, J.; Zahajská, L.; Doležal, K.; Strnad, M. N9-Substituted N6 -[(3-Methylbut-2En-1-Yl)Amino]Purine Derivatives and Their Biological Activity in Selected Cytokinin Bioassays. Bioorg. Med. Chem. 2011, 19, 7244-7251. [CrossRef]

17. Pokorná, E.; Hluska, T.; Galuszka, P.; Hallmark, H.T.; Dobrev, P.I.; Záveská Drábková, L.; Filipi, T.; Holubová, K.; Plíhal, O.; Rashotte, A.M.; et al. Cytokinin N-Glucosides: Occurrence, Metabolism and Biological Activities in Plants. Biomolecules 2021, 11, 24. [CrossRef]

18. Galuszka, P.; Popelková, H.; Werner, T.; Frébortová, J.; Pospíšilová, H.; Mik, V.; Köllmer, I.; Schmülling, T.; Frébort, I. Biochemical Characterization of Cytokinin Oxidases/Dehydrogenases from Arabidopsis Thaliana Expressed in Nicotiana Tabacum L. J. Plant Growth Regul. 2007, 26, 255-267. [CrossRef]

19. Zalabák, D.; Galuszka, P.; Mrízová, K.; Podlešáková, K.; Gu, R.; Frébortová, J. Biochemical Characterization of the Maize Cytokinin Dehydrogenase Family and Cytokinin Profiling in Developing Maize Plantlets in Relation to the Expression of Cytokinin Dehydrogenase Genes. Plant Physiol. Biochem. PPB Société Fr. Physiol. Végétale 2014, 74, 283-293. [CrossRef]

20. Pertry, I.; Václavíková, K.; Depuydt, S.; Galuszka, P.; Spíchal, L.; Temmerman, W.; Stes, E.; Schmülling, T.; Kakimoto, T.; Van Montagu, M.C.E.; et al. Identification of Rhodococcus Fascians Cytokinins and Their Modus Operandi to Reshape the Plant. Proc. Natl. Acad. Sci. USA 2009, 106, 929-934. [CrossRef]

21. Žižková, E.; Dobrev, P.I.; Muhovski, Y.; Hošek, P.; Hoyerová, K.; Haisel, D.; Procházková, D.; Lutts, S.; Motyka, V.; Hichri, I. Tomato (Solanum Lycopersicum L.) SIIPT3 and SIIPT4 Isopentenyltransferases Mediate Salt Stress Response in Tomato. BMC Plant Biol. 2015, 15, 85. [CrossRef]

22. Jaworek, P.; Kopečný, D.; Zalabák, D.; Šebela, M.; Kouřil, Š.; Hluska, T.; Končitíková, R.; Podlešáková, K.; Tarkowski, P. Occurrence and Biosynthesis of Cytokinins in Poplar. Planta 2019, 250, 229-244. [CrossRef]

23. Kasahara, H.; Takei, K.; Ueda, N.; Hishiyama, S.; Yamaya, T.; Kamiya, Y.; Yamaguchi, S.; Sakakibara, H. Distinct Isoprenoid Origins of Cis- and Trans.-Zeatin Biosyntheses in Arabidopsis. J. Biol. Chem. 2004, 279, 14049-14054. [CrossRef] [PubMed]

24. Takei, K.; Ueda, N.; Aoki, K.; Kuromori, T.; Hirayama, T.; Shinozaki, K.; Yamaya, T.; Sakakibara, H. AtIPT3 Is a Key Determinant of Nitrate-Dependent Cytokinin Biosynthesis in Arabidopsis. Plant Cell Physiol. 2004, 45, 1053-1062. [CrossRef] [PubMed]

25. Kuroha, T.; Tokunaga, H.; Kojima, M.; Ueda, N.; Ishida, T.; Nagawa, S.; Fukuda, H.; Sugimoto, K.; Sakakibara, H. Functional Analyses of LONELY GUY Cytokinin-Activating Enzymes Reveal the Importance of the Direct Activation Pathway in Arabidopsis. Plant Cell 2009, 21, 3152-3169. [CrossRef] [PubMed]

26. Cedzich, A.; Stransky, H.; Schulz, B.; Frommer, W.B. Characterization of Cytokinin and Adenine Transport in Arabidopsis Cell Cultures. Plant. Physiol. 2008, 148, 1857-1867. [CrossRef] [PubMed]

27. Gajdošová, S.; Spíchal, L.; Kamínek, M.; Hoyerová, K.; Novák, O.; Dobrev, P.I.; Galuszka, P.; Klíma, P.; Gaudinová, A.; Žižková, E.; et al. Distribution, Biological Activities, Metabolism, and the Conceivable Function of Cis-Zeatin-Type Cytokinins in Plants. J. Exp. Bot. 2011, 62, 2827-2840. [CrossRef] [PubMed]

28. Schäfer, M.; Brütting, C.; Meza-Canales, I.D.; Großkinsky, D.K.; Vaňková, R.; Baldwin, I.T.; Meldau, S. The Role of Cis-Zeatin-Type Cytokinins in Plant Growth Regulation and Mediating Responses to Environmental Interactions. J. Exp. Bot. 2015, 66, 4873-4884. [CrossRef] [PubMed]

29. Hall, R.H.; Csonka, L.; David, H.; McLennan, B. Cytokinins in the Soluble RNA of Plant Tissues. Science 1967, 156, 69-71. [CrossRef]

30. Mok, M.C.; Mok, D.W.S.; Armstrong, D.J. Differential Cytokinin Structure-Activity Relationships in Phaseolus. Plant Physiol. 1978, 61, 72-75. [CrossRef]

31. Schmitz, R.Y.; Skoog, F.; Playtis, A.J.; Leonard, N.J. Cytokinins: Synthesis and Biological Activity of Geometric and Position Isomers of Zeatin. Plant Physiol. 1972, 50, 702-705. [CrossRef]

32. Vreman, H.J.; Schmitz, R.Y.; Skoog, F.; Playtis, A.J.; Frihart, C.R.; Leonard, N.J. Synthesis of 2-Methylthio-Cis- and Trans.Ribosylzeatin and Their Isolation from Pisum TRNA. Phytochemistry 1974, 13, 31-37. [CrossRef]

33. Mauk, C.S.; Langille, A.R. Physiology of Tuberization in Solanum Tuberosum L.: Cis-Zeatin Riboside in the Potato Plant: Its Identification and Changes in Endogenous Levels as Influenced by Temperature and Photoperiod. Plant Physiol. 1978, 62, 438-442. [CrossRef] [PubMed]

34. Suttle, J.C.; Banowetz, G.M. Changes in Cis-Zeatin and Cis-Zeatin Riboside Levels and Biological Activity during Potato Tuber Dormancy. Physiol. Plant. 2000, 109, 68-74. [CrossRef]

35. Lulai, E.C.; Suttle, J.C.; Olson, L.L.; Neubauer, J.D.; Campbell, L.G.; Campbell, M.A. Wounding Induces Changes in Cytokinin and Auxin Content in Potato Tuber, but Does Not Induce Formation of Gibberellins. J. Plant Physiol. 2016, 191, 22-28. [CrossRef] [PubMed] 
36. Kolachevskaya, O.O.; Sergeeva, L.I.; Floková, K.; Getman, I.A.; Lomin, S.N.; Alekseeva, V.V.; Rukavtsova, E.B.; Buryanov, Y.I.; Romanov, G.A. Auxin Synthesis Gene Tms1 Driven by Tuber-Specific Promoter Alters Hormonal Status of Transgenic Potato Plants and Their Responses to Exogenous Phytohormones. Plant Cell Rep. 2017, 36, 419-435. [CrossRef] [PubMed]

37. Watanabe, N.; Yokota, T.; Takahashi, N. Transfer RNA, a Possible Supplier of Free Cytokinins, Ribosyl-Cis-Zeatin and Ribosyl-2Methylthiozeatin: Quantitative Comparison between Free and Transfer Cytokinins in Various Tissues of the Hop Plant. Plant Cell Physiol. 1982, 23, 479-488. [CrossRef]

38. Kudo, T.; Makita, N.; Kojima, M.; Tokunaga, H.; Sakakibara, H. Cytokinin Activity of Cis-Zeatin and Phenotypic Alterations Induced by Overexpression of Putative Cis-Zeatin-O-Glucosyltransferase in Rice. Plant Physiol. 2012, 160, 319-331. [CrossRef]

39. Takagi, M.; Yokota, T.; Murofushi, N.; Ota, Y.; Takahashi, N. Fluctuation of Endogenous Cytokinin Contents in Rice during Its Life Cycle-Quantification of Cytokinins by Selected Ion Monitoring Using Deuterium-Labelled Internal Standards. Agric. Biol. Chem. 1985, 49, 3271-3277. [CrossRef]

40. Emery, R.J.N.; Ma, Q.; Atkins, C.A. The Forms and Sources of Cytokinins in Developing White Lupine Seeds and Fruits. Plant Physiol. 2000, 123, 1593-1604. [CrossRef]

41. Emery, R.J.N.; Leport, L.; Barton, J.E.; Turner, N.C.; Atkins, C.A. Cis-Isomers of Cytokinins Predominate in Chickpea Seeds throughout Their Development. Plant Physiol. 1998, 117, 1515-1523. [CrossRef]

42. Veach, Y.K.; Martin, R.C.; Mok, D.W.S.; Malbeck, J.; Vaňková, R.; Mok, M.C. O-Glucosylation of Cis-Zeatin in Maize. Characterization of Genes, Enzymes, and Endogenous Cytokinins. Plant Physiol. 2003, 131, 1374-1380. [CrossRef] [PubMed]

43. Vyroubalová, Š.; Václavíková, K.; Turečková, V.; Novák, O.; Šmehilová, M.; Hluska, T.; Ohnoutková, L.; Frébort, I.; Galuszka, P. Characterization of New Maize Genes Putatively Involved in Cytokinin Metabolism and Their Expression during Osmotic Stress in Relation to Cytokinin Levels. Plant Physiol. 2009, 151, 433-447. [CrossRef] [PubMed]

44. Stirk, W.A.; Gold, J.D.; Novák, O.; Strnad, M.; van Staden, J. Changes in Endogenous Cytokinins During Germination and Seedling Establishment of Tagetes Minuta L. Plant Growth Regul. 2005, 47, 1-7. [CrossRef]

45. Stirk, W.A.; Novák, O.; Žižková, E.; Motyka, V.; Strnad, M.; van Staden, J. Comparison of Endogenous Cytokinins and Cytokinin Oxidase/Dehydrogenase Activity in Germinating and Thermoinhibited Tagetes Minuta Achenes. J. Plant Physiol. 2012, 169, 696-703. [CrossRef] [PubMed]

46. Quesnelle, P.E.; Emery, R.J.N. Cis-Cytokinins That Predominate in Pisum Sativum during Early Embryogenesis Will Accelerate Embryo Growth in Vitro. Can. J. Bot. 2007, 85, 91-103. [CrossRef]

47. Goggin, D.E.; Emery, R.J.N.; Powles, S.B.; Steadman, K.J. Initial Characterisation of Low and High Seed Dormancy Populations of Lolium Rigidum Produced by Repeated Selection. J. Plant Physiol. 2010, 167, 1282-1288. [CrossRef] [PubMed]

48. Stirk, W.A.; Václavíková, K.; Novák, O.; Gajdošová, S.; Kotland, O.; Motyka, V.; Strnad, M.; van Staden, J. Involvement of Cis-Zeatin, Dihydrozeatin, and Aromatic Cytokinins in Germination and Seedling Establishment of Maize, Oats, and Lucerne. J. Plant Growth Regul. 2012, 31, 392-405. [CrossRef]

49. Tarkowská, D.; Filek, M.; Biesaga-Kościelniak, J.; Marcińska, I.; Macháčková, I.; Krekule, J.; Strnad, M. Cytokinins in Shoot Apices of Brassica Napus Plants during Vernalization. Plant Sci. 2012, 187, 105-112. [CrossRef]

50. Vondráková, Z.; Dobrev, P.I.; Pesek, B.; Fischerová, L.; Vágner, M.; Motyka, V. Profiles of Endogenous Phytohormones Over the Course of Norway Spruce Somatic Embryogenesis. Front. Plant Sci. 2018, 9. [CrossRef]

51. Záveská Drábková, L.; Dobrev, P.I.; Motyka, V. Phytohormone Profiling across the Bryophytes. PLoS ONE 2015, 10, e0125411. [CrossRef]

52. Žižková, E.; Kubeš, M.; Dobrev, P.I.; Přibyl, P.; Šimura, J.; Zahajská, L.; Záveská Drábková, L.; Novák, O.; Motyka, V. Control of Cytokinin and Auxin Homeostasis in Cyanobacteria and Algae. Ann. Bot. 2017, 119, 151-166. [CrossRef] [PubMed]

53. Morrison, E.N.; Knowles, S.; Hayward, A.; Thorn, R.G.; Saville, B.J.; Emery, R.J.N. Detection of Phytohormones in Temperate Forest Fungi Predicts Consistent Abscisic Acid Production and a Common Pathway for Cytokinin Biosynthesis. Mycologia 2015, 107, 245-257. [CrossRef] [PubMed]

54. Miyawaki, K.; Tarkowski, P.; Matsumoto-Kitano, M.; Kato, T.; Sato, S.; Tarkowska, D.; Tabata, S.; Sandberg, G.; Kakimoto, T. Roles of Arabidopsis ATP/ADP Isopentenyltransferases and TRNA Isopentenyltransferases in Cytokinin Biosynthesis. Proc. Natl. Acad. Sci. USA 2006, 103, 16598-16603. [CrossRef] [PubMed]

55. Köllmer, I.; Novák, O.; Strnad, M.; Schmülling, T.; Werner, T. Overexpression of the Cytosolic Cytokinin Oxidase/Dehydrogenase (CKX7) from Arabidopsis Causes Specific Changes in Root Growth and Xylem Differentiation. Plant J. Cell Mol. Biol. 2014, 78, 359-371. [CrossRef] [PubMed]

56. Werner, T.; Motyka, V.; Strnad, M.; Schmülling, T. Regulation of Plant Growth by Cytokinin. Proc. Natl. Acad. Sci. USA 2001, 98, 10487-10492. [CrossRef]

57. Martin, R.C.; Mok, M.C.; Habben, J.E.; Mok, D.W.S. A Maize Cytokinin Gene Encoding an O-Glucosyltransferase Specific to Cis-Zeatin. Proc. Natl. Acad. Sci. USA 2001, 98, 5922-5926. [CrossRef]

58. Spíchal, L.; Rakova, N.Y.; Riefler, M.; Mizuno, T.; Romanov, G.A.; Strnad, M.; Schmülling, T. Two Cytokinin Receptors of Arabidopsis Thaliana, CRE1/AHK4 and AHK3, Differ in Their Ligand Specificity in a Bacterial Assay. Plant Cell Physiol. 2004, 45, 1299-1305. [CrossRef]

59. Yonekura-Sakakibara, K.; Kojima, M.; Yamaya, T.; Sakakibara, H. Molecular Characterization of Cytokinin-Responsive Histidine Kinases in Maize. Differential Ligand Preferences and Response to Cis-Zeatin. Plant Physiol. 2004, 134, 1654-1661. [CrossRef] 
60. Park, E.J.; Kim, T.-H. Fine-Tuning of Gene Expression by TRNA-Derived Fragments during Abiotic Stress Signal Transduction. Int. J. Mol. Sci. 2018, 19, 518. [CrossRef]

61. Kamínek, M. Letter: Evolution of TRNA and Origin of the Two Positional Isomers of Zeatin. J. Theor. Biol. 1974, 48, 489-492. [CrossRef]

62. Kamínek, M. Tracking the Story of Cytokinin Research. J. Plant Growth Regul. 2015, 34, 723-739. [CrossRef]

63. Podlešáková, K.; Fardoux, J.; Patrel, D.; Bonaldi, K.; Novák, O.; Strnad, M.; Giraud, E.; Spíchal, L.; Nouwen, N. Rhizobial Synthesized Cytokinins Contribute to but Are Not Essential for the Symbiotic Interaction between Photosynthetic Bradyrhizobia and Aeschynomene Legumes. Mol. Plant Microbe Interact. MPMI 2013, 26, 1232-1238. [CrossRef] [PubMed]

64. Hinsch, J.; Galuszka, P.; Tudzynski, P. Functional Characterization of the First Filamentous Fungal TRNA-Isopentenyltransferase and Its Role in the Virulence of Claviceps Purpurea. New Phytol. 2016, 211, 980-992. [CrossRef] [PubMed]

65. Koshimizu, K.; Kusaki, T.; Mitsui, T.; Matsubara, S. Isolation of a Cytokinin, (-)-Dihydrozeatin, from Immature Seeds of Lupinus Luteus. Tetrahedron Lett. 1967, 8, 1317-1320. [CrossRef]

66. Koshimizu, K.; Matsubara, S.; Kusaki, T.; Mitsui, T. Isolation of a New Cytokinin from Immature Yellow Lupin Seeds. Agric. Biol. Chem. 1967, 31, 795-801. [CrossRef]

67. Choi, J.; Lee, J.; Kim, K.; Cho, M.; Ryu, H.; An, G.; Hwang, I. Functional Identification of OsHk6 as a Homotypic Cytokinin Receptor in Rice with Preferential Affinity for IP. Plant Cell Physiol. 2012, 53, 1334-1343. [CrossRef]

68. Kuderová, A.; Gallová, L.; Kuricová, K.; Nejedlá, E.; Čurdová, A.; Micenková, L.; Plíhal, O.; Šmajs, D.; Spíchal, L.; Hejátko, J. Identification of AHK2- and AHK3-like Cytokinin Receptors in Brassica Napus Reveals Two Subfamilies of AHK2 Orthologues. J. Exp. Bot. 2015, 66, 339-353. [CrossRef]

69. Lomin, S.N.; Yonekura-Sakakibara, K.; Romanov, G.A.; Sakakibara, H. Ligand-Binding Properties and Subcellular Localization of Maize Cytokinin Receptors. J. Exp. Bot. 2011, 62, 5149-5159. [CrossRef]

70. Romanov, G.A.; Lomin, S.N.; Schmülling, T. Biochemical Characteristics and Ligand-Binding Properties of Arabidopsis Cytokinin Receptor AHK3 Compared to CRE1/AHK4 as Revealed by a Direct Binding Assay. J. Exp. Bot. 2006, 57, 4051-4058. [CrossRef]

71. Gaudinová, A.; Dobrev, P.I.; Šolcová, B.; Novák, O.; Strnad, M.; Friedecký, D.; Motyka, V. The Involvement of Cytokinin Oxidase/Dehydrogenase and Zeatin Reductase in Regulation of Cytokinin Levels in Pea (Pisum Sativum L.) Leaves. J. Plant Growth Regul. 2005, 24, 188-200. [CrossRef]

72. Martin, R.C.; Mok, M.C.; Shaw, G.; Mok, D.W.S. An Enzyme Mediating the Conversion of Zeatin to Dihydrozeatin in Phaseolus Embryos. Plant Physiol. 1989, 90, 1630-1635. [CrossRef]

73. Sondheimer, E.; Tzou, D.-S. The Metabolism of Hormones during Seed Germination and Dormancy II. The Metabolism of ${ }_{8-}{ }^{14}$ C-Zeatin in Bean Axes. Plant Physiol. 1971, 47, 516-520. [CrossRef] [PubMed]

74. Singh, S.; Letham, D.S.; Jameson, P.E.; Zhang, R.; Parker, C.W.; Bandenoch-Jones, J.; Noodén, L.D. Cytokinin Biochemistry in Relation to Leaf Senescence: IV. Cytokinin Metabolism in Soybean Explants. Plant Physiol. 1988, 88, 788-794. [CrossRef] [PubMed]

75. Podlešáková, K.; Zalabák, D.; Čudejková, M.; Plíhal, O.; Szüčová, L.; Doležal, K.; Spíchal, L.; Strnad, M.; Galuszka, P. Novel Cytokinin Derivatives Do Not Show Negative Effects on Root Growth and Proliferation in Submicromolar Range. PLoS ONE 2012, 7, e39293. [CrossRef]

76. Arnau, J.A.; Tadeo, F.R.; Guerri, J.; Primo-Millo, E. Cytokinins in Peach: Endogenous Levels during Early Fruit Development. Plant Physiol. Biochem. 1999, 37, 741-750. [CrossRef]

77. Strnad, M. The Aromatic Cytokinins. Physiol. Plant. 1997, 101, 674-688. [CrossRef]

78. Tarkowská, D.; Dolezal, K.; Tarkowski, P.; Astot, C.; Holub, J.; Fuksová, K.; Schmülling, T.; Sandberg, G.; Strnad, M. Identification of New Aromatic Cytokinins in Arabidopsis Thaliana and Populus x Canadensis Leaves by LC-(+)ESI-MS and Capillary Liquid Chromatography/Frit-Fast Atom Bombardment Mass Spectrometry. Physiol. Plant. 2003, 117, 579-590. [CrossRef]

79. Miller, C.O.; Skoog, F.; Okumura, F.S.; Von Saltza, M.H.; Strong, F.M. Structure and Synthesis of Kinetin. J. Am. Chem. Soc. 1955, 77, 2662-2663. [CrossRef]

80. Haidoune, M.; Mornet, R.; Laloue, M. Synthesis of 6-(3-Methylpyrrol-1-Yl)-9- $\beta$-D-Ribofuranosyl Purine, a Novel Metabolite of Zeatin Riboside. Tetrahedron Lett. 1990, 31, 1419-1422. [CrossRef]

81. Hluska, T.; Dobrev, P.I.; Tarkowská, D.; Frébortová, J.; Zalabák, D.; Kopečný, D.; Plíhal, O.; Kokáš, F.; Briozzo, P.; Zatloukal, M.; et al. Cytokinin Metabolism in Maize: Novel Evidence of Cytokinin Abundance, Interconversions and Formation of a New Trans.-Zeatin Metabolic Product with a Weak Anticytokinin Activity. Plant Sci. 2016, 247, 127-137. [CrossRef]

82. Sørensen, J.L.; Benfield, A.H.; Wollenberg, R.D.; Westphal, K.; Wimmer, R.; Nielsen, M.R.; Nielsen, K.F.; Carere, J.; Covarelli, L.; Beccari, G.; et al. The Cereal Pathogen Fusarium Pseudograminearum Produces a New Class of Active Cytokinins during Infection. Mol. Plant Pathol. 2018, 19, 1140-1154. [CrossRef] [PubMed]

83. Laloue, M.; Fox, J.E. Cytokinin Oxidase from Wheat: Partial Purification and General Properties. Plant Physiol. 1989, 90, 899-906. [CrossRef] [PubMed]

84. Mok, M.C.; Martin, R.C.; Dobrev, P.I.; Vanková, R.; Ho, P.S.; Yonekura-Sakakibara, K.; Sakakibara, H.; Mok, D.W.S. Topolins and Hydroxylated Thidiazuron Derivatives Are Substrates of Cytokinin O-Glucosyltransferase with Position Specificity Related to Receptor Recognition. Plant Physiol. 2005, 137, 1057-1066. [CrossRef] [PubMed]

85. Yong, J.W.H.; Ge, L.; Ng, Y.F.; Tan, S.N. The Chemical Composition and Biological Properties of Coconut (Cocos Nucifera L.) Water. Molecules 2009, 14, 5144-5164. [CrossRef] [PubMed] 
86. Stirk, W.A.; Novák, O.; Václavíková, K.; Tarkowski, P.; Strnad, M.; van Staden, J. Spatial and Temporal Changes in Endogenous Cytokinins in Developing Pea Roots. Planta 2008, 227, 1279-1289. [CrossRef] [PubMed]

87. Doležal, K.; Åstot, C.; Hanuš, J.; Holub, J.; Peters, W.; Beck, E.; Strnad, M.; Sandberg, G. Identification of Aromatic Cytokinins in Suspension Cultured Photoautotrophic Cells of Chenopodium Rubrum by Capillary Liquid Chromatography/Frit-Fast Atom Bombarded Mass Spectrometry. Plant Growth Regul. 2002, 36, 181-189. [CrossRef]

88. Edlund, E.; Novák, O.; Karady, M.; Ljung, K.; Jansson, S. Contrasting Patterns of Cytokinins between Years in Senescing Aspen Leaves. Plant Cell Environ. 2017, 40, 622-634. [CrossRef]

89. Horgan, R.; Hewett, E.W.; Purse, J.G.; Wareing, P.F. A New Cytokinin from Populus Robusta. Tetrahedron Lett. 1973, 14, $2827-2828$. [CrossRef]

90. Chaves das Neves, H.J.; Pais, M.S.S. Identification of a Spathe Regreening Factor in Zantedeschia Aethiopica. Biochem. Biophys. Res. Commun. 1980, 95, 1387-1392. [CrossRef]

91. Ge, L.; Yong, J.W.H.; Tan, S.N.; Yang, X.H.; Ong, E.S. Analysis of Positional Isomers of Hydroxylated Aromatic Cytokinins by Micellar Electrokinetic Chromatography. Electrophoresis 2005, 26, 1768-1777. [CrossRef]

92. De Meutter, J.; Tytgat, T.; Witters, E.; Gheysen, G.; Van Onckelen, H.; Gheysen, G. Identification of Cytokinins Produced by the Plant Parasitic Nematodes Heterodera Schachtii and Meloidogyne Incognita. Mol. Plant Pathol. 2003, 4, 271-277. [CrossRef]

93. Murfin, K.E.; Dillman, A.R.; Foster, J.M.; Bulgheresi, S.; Slatko, B.E.; Sternberg, P.W.; Goodrich-Blair, H. Nematode-Bacterium Symbioses-Cooperation and Conflict Revealed in the "Omics" Age. Biol. Bull. 2012, 223, 85-102. [CrossRef] [PubMed]

94. Juříková, S. Cytokininy v Řasách. Bachelor's Thesis, Universita Palackého v Olomouci, Olomouc, Czech Republic, 2016.

95. Kieber, J.J.; Schaller, G.E. Cytokinin Signaling in Plant Development. Dev. Camb. Engl. 2018, 145. [CrossRef]

96. Rohmer, M. The Discovery of a Mevalonate-Independent Pathway for Isoprenoid Biosynthesis in Bacteria, Algae and Higher Plants. Nat. Prod. Rep. 1999, 16, 565-574. [CrossRef] [PubMed]

97. Kuzuyama, T.; Seto, H. Diversity of the Biosynthesis of the Isoprene Units. Nat. Prod. Rep. 2003, 20, 171-183. [CrossRef] [PubMed]

98. Kamada-Nobusada, T.; Sakakibara, H. Molecular Basis for Cytokinin Biosynthesis. Phytochemistry 2009, 70, 444-449. [CrossRef]

99. Laule, O.; Fürholz, A.; Chang, H.-S.; Zhu, T.; Wang, X.; Heifetz, P.B.; Gruissem, W.; Lange, M. Crosstalk between Cytosolic and Plastidial Pathways of Isoprenoid Biosynthesis in Arabidopsis Thaliana. Proc. Natl. Acad. Sci. USA 2003, 100, 6866-6871. [CrossRef]

100. Sakakibara, H.; Kasahara, H.; Ueda, N.; Kojima, M.; Takei, K.; Hishiyama, S.; Asami, T.; Okada, K.; Kamiya, Y.; Yamaya, T.; et al. Agrobacterium Tumefaciens Increases Cytokinin Production in Plastids by Modifying the Biosynthetic Pathway in the Host Plant. Proc. Natl. Acad. Sci. USA 2005, 102, 9972-9977. [CrossRef]

101. Abe, I.; Tanaka, H.; Abe, T.; Noguchi, H. Enzymatic Formation of Unnatural Cytokinin Analogs by Adenylate Isopentenyltransferase from Mulberry. Biochem. Biophys. Res. Commun. 2007, 355, 795-800. [CrossRef]

102. Chu, H.-M.; Ko, T.-P.; Wang, A.H.-J. Crystal Structure and Substrate Specificity of Plant Adenylate Isopentenyltransferase from Humulus Lupulus: Distinctive Binding Affinity for Purine and Pyrimidine Nucleotides. Nucleic Acids Res. 2010, 38, 1738-1748. [CrossRef]

103. Chu, H.-M.; Chen, F.-Y.; Ko, T.-P.; Wang, A.H.-J. Binding and Catalysis of Humulus Lupulus Adenylate Isopentenyltransferase for the Synthesis of Isopentenylated Diadenosine Polyphosphates. FEBS Lett. 2010, 584, 4083-4088. [CrossRef] [PubMed]

104. Skoog, F.; Hamzi, H.Q.; Szweykowska, A.M.; Leonard, N.J.; Carraway, K.L.; Fujii, T.; Helgeson, J.P.; Loeppky, R.N. Cytokinins: Structure/Activity Relationships. Phytochemistry 1967, 6, 1169-1192. [CrossRef]

105. Miyawaki, K.; Matsumoto-Kitano, M.; Kakimoto, T. Expression of Cytokinin Biosynthetic Isopentenyltransferase Genes in Arabidopsis: Tissue Specificity and Regulation by Auxin, Cytokinin, and Nitrate. Plant J. 2004, 37, 128-138. [CrossRef] [PubMed]

106. Sakamoto, T.; Sakakibara, H.; Kojima, M.; Yamamoto, Y.; Nagasaki, H.; Inukai, Y.; Sato, Y.; Matsuoka, M. Ectopic Expression of KNOTTED1-like Homeobox Protein Induces Expression of Cytokinin Biosynthesis Genes in Rice. Plant Physiol. 2006, $142,54-62$. [CrossRef] [PubMed]

107. Ye, C.; Wu, S.; Kong, F.; Zhou, C.; Yang, Q.; Sun, Y.; Wang, B. Identification and Characterization of an Isopentenyltransferase (IPT) Gene in Soybean (Glycine Max L.). Plant Sci. 2006, 170, 542-550. [CrossRef]

108. Liu, Z.; Lv, Y.; Zhang, M.; Liu, Y.; Kong, L.; Zou, M.; Lu, G.; Cao, J.; Yu, X. Identification, Expression, and Comparative Genomic Analysis of the IPT and CKX Gene Families in Chinese Cabbage (Brassica Rapa ssp. Pekinensis). BMC Genom. 2013, 14, 594. [CrossRef]

109. Chen, Y.; Chen, W.; Li, X.; Jiang, H.; Wu, P.; Xia, K.; Yang, Y.; Wu, G. Knockdown of LjIPT3 Influences Nodule Development in Lotus Japonicus. Plant Cell Physiol. 2014, 55, 183-193. [CrossRef]

110. Song, J.; Jiang, L.; Jameson, P.E. Expression Patterns of Brassica Napus Genes Implicate IPT, CKX, Sucrose Transporter, Cell Wall Invertase, and Amino Acid Permease Gene Family Members in Leaf, Flower, Silique, and Seed Development. J. Exp. Bot. 2015, 66, 5067-5082. [CrossRef]

111. Li, M.; Wei, Q.; Xiao, Y.; Peng, F. The Effect of Auxin and Strigolactone on ATP/ADP Isopentenyltransferase Expression and the Regulation of Apical Dominance in Peach. Plant Cell Rep. 2018, 37, 1693-1705. [CrossRef]

112. Tanaka, M.; Takei, K.; Kojima, M.; Sakakibara, H.; Mori, H. Auxin Controls Local Cytokinin Biosynthesis in the Nodal Stem in Apical Dominance. Plant J. Cell Mol. Biol. 2006, 45, 1028-1036. [CrossRef]

113. Landrein, B.; Formosa-Jordan, P.; Malivert, A.; Schuster, C.; Melnyk, C.W.; Yang, W.; Turnbull, C.G.N.; Meyerowitz, E.M.; Locke, J.C.W.; Jönsson, H. Nitrate Modulates Stem Cell Dynamics in Arabidopsis Shoot Meristems through Cytokinins. Proc. Natl. Acad. Sci. USA 2018, 115, 1382-1387. [CrossRef] [PubMed] 
114. Wang, J.; Lu, K.; Nie, H.; Zeng, Q.; Wu, B.; Qian, J.; Fang, Z. Rice Nitrate Transporter OsNPF7.2 Positively Regulates Tiller Number and Grain Yield. Rice 2018, 11, 12. [CrossRef] [PubMed]

115. Galichet, A.; Hoyerová, K.; Kamínek, M.; Gruissem, W. Farnesylation Directs AtIPT3 Subcellular Localization and Modulates Cytokinin Biosynthesis in Arabidopsis. Plant Physiol. 2008, 146, 1155-1164. [CrossRef] [PubMed]

116. Miura, G.A.; Miller, C.O. 6-( $\gamma, \gamma$-Dimethylallylamino)Purine As A Precursor of Zeatin. Plant Physiol. 1969, 44, 372-376. [CrossRef]

117. Miura, G.A.; Hall, R.H. Trans-Ribosylzeatin: Its Biosynthesis in Zea Mays Endosperm and the Mycorrhizal Fungus, Rhizopogon Roseolus. Plant Physiol. 1973, 51, 563-569. [CrossRef]

118. Chen, C.M.; Leisner, S.M. Modification of Cytokinins by Cauliflower Microsomal Enzymes. Plant Physiol. 1984, 75, 442-446. [CrossRef]

119. Takei, K.; Yamaya, T.; Sakakibara, H. Arabidopsis CYP735A1 and CYP735A2 Encode Cytokinin Hydroxylases That Catalyze the Biosynthesis of Trans.-Zeatin. J. Biol. Chem. 2004, 279, 41866-41872. [CrossRef]

120. Kiba, T.; Takei, K.; Kojima, M.; Sakakibara, H. Side-Chain Modification of Cytokinins Controls Shoot Growth in Arabidopsis. Dev. Cell 2013, 27, 452-461. [CrossRef]

121. Chang, L.; Ramireddy, E.; Schmülling, T. Cytokinin as a Positional Cue Regulating Lateral Root Spacing in Arabidopsis. J. Exp. Bot. 2015, 66, 4759-4768. [CrossRef]

122. Persson, B.C.; Björk, G.R. Isolation of the Gene (MiaE) Encoding the Hydroxylase Involved in the Synthesis of 2-Methylthio-CisRibozeatin in TRNA of Salmonella Typhimurium and Characterization of Mutants. J. Bacteriol. 1993, 175, 7776-7785. [CrossRef]

123. Kaminska, K.H.; Baraniak, U.; Boniecki, M.; Nowaczyk, K.; Czerwoniec, A.; Bujnicki, J.M. Structural Bioinformatics Analysis of Enzymes Involved in the Biosynthesis Pathway of the Hypermodified Nucleoside $\mathrm{Ms}^{2} \mathrm{Io}^{6} \mathrm{~A} 37$ in TRNA. Proteins Struct. Funct. Bioinform. 2008, 70, 1-18. [CrossRef] [PubMed]

124. Bassil, N.V.; Mok, D.W.S.; Mok, M.C. Partial Purification of a Cis-Trans.-Isomerase of Zeatin from Immature Seed of Phaseolus Vulgaris L. Plant Physiol. 1993, 102, 867-872. [CrossRef] [PubMed]

125. Sasaki, E.; Ogura, T.; Takei, K.; Kojima, M.; Kitahata, N.; Sakakibara, H.; Asami, T.; Shimada, Y. Uniconazole, a Cytochrome P450 Inhibitor, Inhibits Trans.-Zeatin Biosynthesis in Arabidopsis. Phytochemistry 2013, 87, 30-38. [CrossRef]

126. Cai, L.; Zhang, L.; Fu, Q.; Xu, Z.-F. Identification and Expression Analysis of Cytokinin Metabolic Genes IPTs, CYP735A and CKXs in the Biofuel Plant Jatropha Curcas. Peer] 2018, 6, e4812. [CrossRef] [PubMed]

127. Eisermann, I.; Motyka, V.; Kümmel, S.; Dobrev, P.I.; Hübner, K.; Deising, H.B.; Wirsel, S.G.R. CgIPT1 Is Required for Synthesis of Cis-Zeatin Cytokinins and Contributes to Stress Tolerance and Virulence in Colletotrichum Graminicola. Fungal Genet. Biol. 2020, 143, 103436. [CrossRef] [PubMed]

128. Hluska, T.; Šebela, M.; Lenobel, R.; Frébort, I.; Galuszka, P. Purification of Maize Nucleotide Pyrophosphatase/Phosphodiesterase Casts Doubt on the Existence of Zeatin Cis-Trans. Isomerase in Plants. Front. Plant Sci. 2017, 8. [CrossRef]

129. Kuroha, T.; Kato, H.; Asami, T.; Yoshida, S.; Kamada, H.; Satoh, S. A Trans.-Zeatin Riboside in Root Xylem Sap Negatively Regulates Adventitious Root Formation on Cucumber Hypocotyls. J. Exp. Bot. 2002, 53, 2193-2200. [CrossRef]

130. Nandi, S.K.; Palni, L.M.S. Metabolism of Zeatin Riboside in a Hormone Autonomous Genetic Tumour Line of Tobacco. Plant Growth Regul. 1997, 23, 159-166. [CrossRef]

131. Trdá, L.; Barešová, M.; Šašek, V.; Nováková, M.; Zahajská, L.; Dobrev, P.I.; Motyka, V.; Burketová, L. Cytokinin Metabolism of Pathogenic Fungus Leptosphaeria Maculans Involves Isopentenyltransferase, Adenosine Kinase and Cytokinin Oxidase/Dehydrogenase. Front. Microbiol. 2017, 8. [CrossRef] [PubMed]

132. Šmehilová, M.; Galuszka, P.; Bilyeu, K.D.; Jaworek, P.; Kowalska, M.; Šebela, M.; Sedlárová, M.; English, J.T.; Frébort, I. Subcellular Localization and Biochemical Comparison of Cytosolic and Secreted Cytokinin Dehydrogenase Enzymes from Maize. J. Exp. Bot. 2009, 60, 2701-2712. [CrossRef]

133. Václavíková, K.; Hluska, T.; Floková, K.; Slováková, K.; Galuszka, P.; Tarkowski, P. The Cytokinin Metabolism in Maize. In Proceedings of the 3rd ACPD International Symposium, Prague, Czech Republic, 10-14 July 2009.

134. Hluska, T. On the Hunt for Zeatin Cis-Trans. Isomerase. Bachelor's Thesis, Palacký University, Olomouc, Czech Republic, 2010.

135. Chen, C. Cytokinin Biosynthesis and Interconversion. Physiol. Plant. 1997, 101, 665-673. [CrossRef]

136. Kurakawa, T.; Ueda, N.; Maekawa, M.; Kobayashi, K.; Kojima, M.; Nagato, Y.; Sakakibara, H.; Kyozuka, J. Direct Control of Shoot Meristem Activity by a Cytokinin-Activating Enzyme. Nature 2007, 445, 652-655. [CrossRef] [PubMed]

137. Hinsch, J.; Vrabka, J.; Oeser, B.; Novák, O.; Galuszka, P.; Tudzynski, P. De Novo Biosynthesis of Cytokinins in the Biotrophic Fungus Claviceps Purpurea. Environ. Microbiol. 2015, 17, 2935-2951. [CrossRef] [PubMed]

138. Samanovic, M.I.; Tu, S.; Novák, O.; Iyer, L.M.; McAllister, F.E.; Aravind, L.; Gygi, S.P.; Hubbard, S.R.; Strnad, M.; Darwin, K.H. Proteasomal Control of Cytokinin Synthesis Protects Mycobacterium Tuberculosis against Nitric Oxide. Mol. Cell 2015, 57, 984-994. [CrossRef]

139. Seo, H.; Kim, S.; Sagong, H.-Y.; Son, H.F.; Jin, K.S.; Kim, I.-K.; Kim, K.-J. Structural Basis for Cytokinin Production by LOG from Corynebacterium Glutamicum. Sci. Rep. 2016, 6, 31390. [CrossRef]

140. Seo, H.; Kim, K.-J. Structural Basis for a Novel Type of Cytokinin-Activating Protein. Sci. Rep. 2017, 7, 45985. [CrossRef]

141. Seo, H.; Kim, K.-J. Structural Insight into Molecular Mechanism of Cytokinin Activating Protein from Pseudomonas Aeruginosa PAO1. Environ. Microbiol. 2018, 20, 3214-3223. [CrossRef] 
142. Mayaka, J.B.; Huang, Q.; Xiao, Y.; Zhong, Q.; Ni, J.; Shen, Y. The Lonely Guy (LOG) Homologue SiRe_0427 from the Thermophilic Archaeon Sulfolobus Islandicus REY15A Is a Phosphoribohydrolase Representing a Novel Group. Appl. Environ. Microbiol. 2019, 85. [CrossRef]

143. Nishii, K.; Wright, F.; Chen, Y.-Y.; Möller, M. Tangled History of a Multigene Family: The Evolution of ISOPENTENYLTRANSFERASE Genes. PLoS ONE 2018, 13, e0201198. [CrossRef]

144. Burroughs, A.M.; Zhang, D.; Schäffer, D.E.; Iyer, L.M.; Aravind, L. Comparative Genomic Analyses Reveal a Vast, Novel Network of Nucleotide-Centric Systems in Biological Conflicts, Immunity and Signaling. Nucleic Acids Res. 2015, 43, 10633-10654. [CrossRef]

145. Tokunaga, H.; Kojima, M.; Kuroha, T.; Ishida, T.; Sugimoto, K.; Kiba, T.; Sakakibara, H. Arabidopsis Lonely Guy (LOG) Multiple Mutants Reveal a Central Role of the LOG-Dependent Pathway in Cytokinin Activation. Plant J. 2012, 69, 355-365. [CrossRef] [PubMed]

146. Creason, A.L.; Vandeputte, O.M.; Savory, E.A.; Davis, E.W.; Putnam, M.L.; Hu, E.; Swader-Hines, D.; Mol, A.; Baucher, M.; Prinsen, E.; et al. Analysis of Genome Sequences from Plant Pathogenic Rhodococcus Reveals Genetic Novelties in Virulence Loci. PLoS ONE 2014, 9, e101996. [CrossRef] [PubMed]

147. Niehaus, E.-M.; Münsterkötter, M.; Proctor, R.H.; Brown, D.W.; Sharon, A.; Idan, Y.; Oren-Young, L.; Sieber, C.M.; Novák, O.; Pěnčík, A.; et al. Comparative "Omics" of the Fusarium Fujikuroi Species Complex Highlights Differences in Genetic Potential and Metabolite Synthesis. Genome Biol. Evol. 2016, 8, 3574-3599. [CrossRef] [PubMed]

148. Hirose, N.; Takei, K.; Kuroha, T.; Kamada-Nobusada, T.; Hayashi, H.; Sakakibara, H. Regulation of Cytokinin Biosynthesis, Compartmentalization and Translocation. J. Exp. Bot. 2008, 59, 75-83. [CrossRef]

149. Osugi, A.; Kojima, M.; Takebayashi, Y.; Ueda, N.; Kiba, T.; Sakakibara, H. Systemic Transport of Trans.-Zeatin and Its Precursor Have Differing Roles in Arabidopsis Shoots. Nat. Plants 2017, 3, 17112. [CrossRef]

150. Kind, S.; Hinsch, J.; Vrabka, J.; Hradilová, M.; Majeská-Čudejková, M.; Tudzynski, P.; Galuszka, P. Manipulation of Cytokinin Level in the Ergot Fungus Claviceps Purpurea Emphasizes Its Contribution to Virulence. Curr. Genet. 2018, 64, 1303-1319. [CrossRef]

151. Pertry, I.; Václavíková, K.; Gemrotová, M.; Spíchal, L.; Galuszka, P.; Depuydt, S.; Temmerman, W.; Stes, E.; De Keyser, A.; Riefler, M.; et al. Rhodococcus Fascians Impacts Plant Development through the Dynamic Fas-Mediated Production of a Cytokinin Mix. Mol. Plant Microbe Interact. 2010, 23, 1164-1174. [CrossRef]

152. Schoor, S.; Farrow, S.; Blaschke, H.; Lee, S.; Perry, G.; von Schwartzenberg, K.; Emery, N.; Moffatt, B. Adenosine Kinase Contributes to Cytokinin Interconversion in Arabidopsis. Plant Physiol. 2011, 157, 659-672. [CrossRef]

153. Zhang, X.; Chen, Y.; Lin, X.; Hong, X.; Zhu, Y.; Li, W.; He, W.; An, F.; Guo, H. Adenine Phosphoribosyl Transferase 1 Is a Key Enzyme Catalyzing Cytokinin Conversion from Nucleobases to Nucleotides in Arabidopsis. Mol. Plant 2013, 6, 1661-1672. [CrossRef]

154. Kwade, Z.; Swiatek, A.; Azmi, A.; Goossens, A.; Inzé, D.; Van Onckelen, H.; Roef, L. Identification of Four Adenosine Kinase Isoforms in Tobacco By-2 Cells and Their Putative Role in the Cell Cycle-Regulated Cytokinin Metabolism. J. Biol. Chem. 2005, 280, 17512-17519. [CrossRef]

155. Bromley, J.R.; Warnes, B.J.; Newell, C.A.; Thomson, J.C.P.; James, C.M.; Turnbull, C.G.N.; Hanke, D.E. A Purine Nucleoside Phosphorylase in Solanum Tuberosum L. (Potato) with Specificity for Cytokinins Contributes to the Duration of Tuber Endodormancy. Biochem. J. 2014, 458, 225-237. [CrossRef] [PubMed]

156. Chen, C.; Kristopeit, S.M. Metabolism of Cytokinin: Deribosylation of Cytokinin Ribonucleoside by Adenosine Nucleosidase from Wheat Germ Cells. Plant Physiol. 1981, 68, 1020-1023. [CrossRef] [PubMed]

157. Chen, C.; Kristopeit, S.M. Metabolism of Cytokinin: Dephosphorylation of cytokinin ribonucleotide by 5'-nucleotidases from wheat germ cytosol. Plant Physiol. 1981, 67, 494-498. [CrossRef] [PubMed]

158. Kakimoto, T. Identification of Plant Cytokinin Biosynthetic Enzymes as Dimethylallyl Diphosphate: ATP/ADP Isopentenyltransferases. Plant Cell Physiol. 2001, 42, 677-685. [CrossRef] [PubMed]

159. Sakano, Y.; Okada, Y.; Matsunaga, A.; Suwama, T.; Kaneko, T.; Ito, K.; Noguchi, H.; Abe, I. Molecular Cloning, Expression, and Characterization of Adenylate Isopentenyltransferase from Hop (Humulus Lupulus L.). Phytochemistry 2004, 65, 2439-2446. [CrossRef]

160. Parker, C.W.; Letham, D.S.; Gollnow, B.I.; Summons, R.E.; Duke, C.C.; Macleod, J.K. Regulators of Cell Division in Plant Tissues: XXV. Metabolism of Zeatin by Lupin Seedlings. Planta 1978, 142, 239-251. [CrossRef]

161. Palni, L.M.; Palmer, M.V.; Letham, D.S. The Stability and Biological Activity of Cytokinin Metabolites in Soybean Callus Tissue. Planta 1984, 160, 242-249. [CrossRef]

162. Badenoch-Jones, J.; Rolfe, B.G.; Letham, D.S. Phytohormones, Rhizobium Mutants, and Nodulation in Legumes V. Cytokinin Metabolism in Effective and Ineffective Pea Root Nodules. Plant Physiol. 1984, 74, 239-246. [CrossRef]

163. Entsch, B.; Letham, D.S.; Parker, C.W.; Summons, R.E.; Gollnow, B.I. Metabolites of Cytokinins. In Proceedings of the Plant Growth Substances 1979; Skoog, F., Ed.; Springer: Berlin/Heidelberg, Germany, 1980; pp. 109-118.

164. Letham, D.S.; Summons, R.E.; Parker, C.W.; MacLeod, J.K. Regulators of Cell Division in Plant Tissues: XXVII. Identification of an Amino-Acid Conjugate of 6-Benzylaminopurine Formed in Phaseolus Vulgaris Seedlings. Planta 1979, 146, 71-74. [CrossRef]

165. Elliott, D.C.; Thompson, M.J. The Identity of the Major Metabolite of Benzylaminopurine in Soybean Cultures, and the Inhibition of Its Formation by Aminophylline. Plant Sci. Lett. 1982, 28, 29-38. [CrossRef] 
166. Entsch, B.; Parker, C.W.; Letham, D.S. An Enzyme from Lupin Seeds Forming Alanine Derivatives of Cytokinins. Phytochemistry 1983, 22, 375-381. [CrossRef]

167. Nomura, T.; Tanaka, Y.; Abe, H.; Uchiyama, M. Cytokinin Activity of Discadenine: A Spore Germination Inhibitor of Dictyostelium Discoideum. Phytochemistry 1977, 16, 1819-1820. [CrossRef]

168. Mik, V.; Mičková, Z.; Doležal, K.; Frébort, I.; Pospíšil, T. Activity of (+)-Discadenine as a Plant Cytokinin. J. Nat. Prod. 2017. [CrossRef] [PubMed]

169. Aoki, M.M.; Kisiala, A.B.; Li, S.; Stock, N.L.; Brunetti, C.R.; Huber, R.J.; Emery, R.J.N. Cytokinin Detection during the Dictyostelium Discoideum Life Cycle: Profiles Are Dynamic and Affect Cell Growth and Spore Germination. Biomolecules 2019, 9, 702. [CrossRef]

170. Adl, S.M.; Simpson, A.G.B.; Lane, C.E.; Lukeš, J.; Bass, D.; Bowser, S.S.; Brown, M.W.; Burki, F.; Dunthorn, M.; Hampl, V.; et al. The Revised Classification of Eukaryotes. J. Eukaryot. Microbiol. 2012, 59, 429-514. [CrossRef]

171. Turner, J.E.; Mok, D.W.S.; Mok, M.C.; Shaw, G. Isolation and Partial Purification of an Enzyme Catalyzing the Formation of O-Xylosylzeatin in Phaseolus Vulgaris Embryos. Proc. Natl. Acad. Sci. USA 1987, 84, 3714-3717. [CrossRef]

172. Taylor, J.S.; Koshioka, M.; Pharis, R.P.; Sweet, G.B. Changes in Cytokinins and Gibberellin-Like Substances in Pinus Radiata Buds during Lateral Shoot Initiation and the Characterization of Ribosyl Zeatin and a Novel Ribosyl Zeatin Glycoside. Plant Physiol. 1984, 74, 626-631. [CrossRef]

173. Zhang, H.; Horgan, K.J.; Stewart Reynolds, P.H.; Norris, G.E.; Jameson, P.E. Novel Cytokinins: The Predominant Forms in Mature Buds of Pinus Radiata. Physiol. Plant. 2001, 112, 127-134. [CrossRef]

174. Kobayashi, H.; Morisaki, N.; Tago, Y.; Hashimoto, Y.; Iwasaki, S.; Kawachi, E.; Nagata, R.; Shudo, K. Identification of a Major Cytokinin in Coconut Milk. Experientia 1995, 51, 1081-1084. [CrossRef]

175. Letham, D.S.; Zhang, R. Cytokinin Translocation and Metabolism in Lupin Species II. New Nucleotide Metabolites of Cytokinins. Plant Sci. 1989, 64, 161-165. [CrossRef]

176. Brzobohatý, B.; Moore, I.; Kristoffersen, P.; Bako, L.; Campos, N.; Schell, J.; Palme, K. Release of Active Cytokinin by a $\beta$-Glucosidase Localized to the Maize Root Meristem. Science 1993, 262, 1051-1054. [CrossRef] [PubMed]

177. Sakakibara, H. Cytokinins: Activity, Biosynthesis, and Translocation. Ann. Rev. Plant. Biol. 2006, 57, 431-449. [CrossRef] [PubMed]

178. Letham, D.S.; Palni, L.M.S. The Biosynthesis and Metabolism of Cytokinins. Ann. Rev. Plant Physiol. 1983, 34, 163-197. [CrossRef]

179. Letham, D.S.; Palni, L.M.S.; Tao, G.-Q.; Gollnow, B.I.; Bates, C.M. Regulators of Cell Division in Plant Tissues XXIX. The Activities of Cytokinin Glucosides and Alanine Conjugates in Cytokinin Bioassays. J. Plant Growth Regul. 1983, 2, 103-115. [CrossRef]

180. Fusseder, A.; Ziegler, P. Metabolism and Compartmentation of Dihydrozeatin Exogenously Supplied to Photoautotrophic Suspension Cultures of Chenopodium Rubrum. Planta 1988, 173, 104-109. [CrossRef]

181. Jiskrová, E.; Novák, O.; Pospíšilová, H.; Holubová, K.; Karády, M.; Galuszka, P.; Robert, S.; Frébort, I. Extra- and Intracellular Distribution of Cytokinins in the Leaves of Monocots and Dicots. New Biotechnol. 2016, 33, 735-742. [CrossRef]

182. Benková, E.; Witters, E.; Van Dongen, W.; Kolář, J.; Motyka, V.; Brzobohatý, B.; Van Onckelen, H.A.; Macháčková, I. Cytokinins in Tobacco and Wheat Chloroplasts. Occurrence and Changes Due to Light/Dark Treatment. Plant Physiol. 1999, 121, $245-252$. [CrossRef]

183. Polanská, L.; Vičánková, A.; Nováková, M.; Malbeck, J.; Dobrev, P.I.; Brzobohatý, B.; Vaňková, R.; Macháčková, I. Altered Cytokinin Metabolism Affects Cytokinin, Auxin, and Abscisic Acid Contents in Leaves and Chloroplasts, and Chloroplast Ultrastructure in Transgenic Tobacco. J. Exp. Bot. 2007, 58, 637-649. [CrossRef]

184. Kiran, N.S.; Benková, E.; Reková, A.; Dubová, J.; Malbeck, J.; Palme, K.; Brzobohatý, B. Retargeting a Maize $\beta$-Glucosidase to the Vacuole-Evidence from Intact Plants That Zeatin-O-Glucoside Is Stored in the Vacuole. Phytochemistry 2012, $79,67-77$. [CrossRef]

185. Fox, J.E.; Cornette, J.; Deleuze, G.; Dyson, W.; Giersak, C.; Niu, P.; Zapata, J.; McChesney, J. The Formation, Isolation, and Biological Activity of a Cytokinin 7-Glucoside. Plant Physiol. 1973, 52, 627-632. [CrossRef]

186. Parker, C.W.; Letham, D.S. Regulators of Cell Division in Plant Tissues. XVI Metabolism of Zeatin by Radish Cotyledons and Hypocotyls. Planta 1973, 114, 199-218. [CrossRef] [PubMed]

187. Hallmark, H.T.; Černý, M.; Brzobohatý, B.; Rashotte, A.M. Trans-Zeatin-N-Glucosides Have Biological Activity in Arabidopsis Thaliana. PLoS ONE 2020, 15, e0232762. [CrossRef] [PubMed]

188. Werner, T.; Motyka, V.; Laucou, V.; Smets, R.; Onckelen, H.V.; Schmülling, T. Cytokinin-Deficient Transgenic Arabidopsis Plants Show Multiple Developmental Alterations Indicating Opposite Functions of Cytokinins in the Regulation of Shoot and Root Meristem Activity. Plant Cell 2003, 15, 2532-2550. [CrossRef] [PubMed]

189. Pospíšilová, H.; Jiskrová, E.; Vojta, P.; Mrízová, K.; Kokáš, F.; Čudejková, M.M.; Bergougnoux, V.; Plíhal, O.; Klimešová, J.; Novák, O.; et al. Transgenic Barley Overexpressing a Cytokinin Dehydrogenase Gene Shows Greater Tolerance to Drought Stress. New Biotechnol. 2016, 33, 692-705. [CrossRef]

190. Lomin, S.N.; Myakushina, Y.A.; Kolachevskaya, O.O.; Getman, I.A.; Arkhipov, D.V.; Savelieva, E.M.; Osolodkin, D.I.; Romanov, G.A. Cytokinin Perception in Potato: New Features of Canonical Players. J. Exp. Bot. 2018, 69, 3839-3853. [CrossRef]

191. Simerský, R.; Chamrád, I.; Kania, J.; Strnad, M.; Šebela, M.; Lenobel, R. Chemical Proteomic Analysis of 6-Benzylaminopurine Molecular Partners in Wheat Grains. Plant Cell Rep. 2017, 36, 1561-1570. [CrossRef]

192. Bajguz, A.; Piotrowska, A. Conjugates of Auxin and Cytokinin. Phytochemistry 2009, 70, 957-969. [CrossRef] 
193. Gawer, M.; Laloue, M.; Terrine, C.; Guern, J. Metabolism and Biological Significance of Benzyladenine-7-Glucoside. Plant Sci. Lett. 1977, 8, 267-274. [CrossRef]

194. Faiss, M.; Strnad, M.; Redig, P.; Doležal, K.; Hanuš, J.; Van Onckelen, H.A.; Schmülling, T. Chemically Induced Expression of the RolC-Encoded $\beta$-Glucosidase in Transgenic Tobacco Plants and Analysis of Cytokinin Metabolism: RolC Does Not Hydrolyze Endogenous Cytokinin Glucosides in Planta. Plant J. 1996, 10, 33-46. [CrossRef]

195. Zhang, R.; Letham, D.S. Cytokinin Biochemistry in Relation to Leaf Senescence. III. The Senescence-Retarding Activity and Metabolism of 9-Substituted 6-Benzylaminopurines in Soybean Leaves. J. Plant Growth Regul. 1989, 8, 181-197. [CrossRef]

196. Hošek, P.; Hoyerová, K.; Kiran, N.S.; Dobrev, P.I.; Zahajská, L.; Filepová, R.; Motyka, V.; Müller, K.; Kamínek, M. Distinct Metabolism of $\mathrm{N}$-Glucosides of Isopentenyladenine and Trans.-Zeatin Determines Cytokinin Metabolic Spectrum in Arabidopsis New Phytol. 2020, 225, 2423-2438. [CrossRef] [PubMed]

197. Entsch, B.; Parker, C.W.; Letham, D.S.; Summons, R.E. Preparation and Characterization, Using High-Performance Liquid Chromatography, of an Enzyme Forming Glucosides of Cytokinins. Biochim. Biophys. Acta BBA Enzymol. 1979, 570, 124-139. [CrossRef]

198. Dixon, S.C.; Martin, R.C.; Mok, M.C.; Shaw, G.; Mok, D.W.S. Zeatin Glycosylation Enzymes in Phaseolus Isolation of OGlucosyltransferase from P. Lunatus and Comparison to O-Xylosyltransferase from P. Vulgaris. Plant Physiol. 1989, 90, 1316-1321. [CrossRef]

199. Martin, R.C.; Mok, M.C.; Mok, D.W.S. A Gene Encoding the Cytokinin Enzyme Zeatin O-Xylosyltransferase of Phaseolus Vulgaris. Plant Physiol. 1999, 120, 553-558. [CrossRef]

200. Martin, R.C.; Mok, M.C.; Mok, D.W.S. Isolation of a Cytokinin Gene, ZOG1, Encoding Zeatin O-Glucosyltransferase from Phaseolus Lunatus. Proc. Natl. Acad. Sci. USA 1999, 96, 284-289. [CrossRef]

201. Hou, B.-K.; Lim, E.-K.; Higgins, G.S.; Bowles, D.J. N-Glucosylation of Cytokinins by Glycosyltransferases of Arabidopsis Thaliana. J. Biol. Chem. 2004, 279, 47822-47832. [CrossRef]

202. Gandia-Herrero, F.; Lorenz, A.; Larson, T.; Graham, I.A.; Bowles, D.J.; Rylott, E.L.; Bruce, N.C. Detoxification of the Explosive 2,4,6-Trinitrotoluene in Arabidopsis: Discovery of Bifunctional $O$ - and C-Glucosyltransferases. Plant J. 2008, 56, 963-974. [CrossRef]

203. Poppenberger, B.; Fujioka, S.; Soeno, K.; George, G.L.; Vaistij, F.E.; Hiranuma, S.; Seto, H.; Takatsuto, S.; Adam, G.; Yoshida, S.; et al. The UGT73C5 of Arabidopsis Thaliana Glucosylates Brassinosteroids. Proc. Natl. Acad. Sci. USA 2005, 102, 15253-15258. [CrossRef]

204. Pineda Rodó, A.; Brugière, N.; Vaňková, R.; Malbeck, J.; Olson, J.M.; Haines, S.C.; Martin, R.C.; Habben, J.E.; Mok, D.W.S.; Mok, M.C. Over-Expression of a Zeatin O-Glucosylation Gene in Maize Leads to Growth Retardation and Tasselseed Formation. J. Exp. Bot. 2008, 59, 2673-2686. [CrossRef]

205. Cucinotta, M.; Manrique, S.; Cuesta, C.; Benková, E.; Novák, O.; Colombo, L. CUP-SHAPED COTYLEDON1 (CUC1) and CUC2 Regulate Cytokinin Homeostasis to Determine Ovule Number in Arabidopsis. J. Exp. Bot. 2018, 69, 5169-5176. [CrossRef]

206. Shang, X.-L.; Xie, R.-R.; Tian, H.; Wang, Q.-L.; Guo, F.-Q. Putative Zeatin O-Glucosyltransferase OscZOG1 Regulates Root and Shoot Development and Formation of Agronomic Traits in Rice. J. Integr. Plant Biol. 2016, 58, 627-641. [CrossRef]

207. Gan, S.; Amasino, R.M. Inhibition of Leaf Senescence by Autoregulated Production of Cytokinin. Science 1995, $270,1986-1988$. [CrossRef]

208. Frébort, I.; Kowalska, M.; Hluska, T.; Frébortová, J.; Galuszka, P. Evolution of Cytokinin Biosynthesis and Degradation. J. Exp. Bot. 2011, 62, 2431-2452. [CrossRef]

209. Schmülling, T.; Werner, T.; Riefler, M.; Krupková, E.; Manns, I.B. y Structure and Function of Cytokinin Oxidase/Dehydrogenase Genes of Maize, Rice, Arabidopsis and Other Species. J. Plant Res. 2003, 116, 241-252. [CrossRef]

210. Pačes, V.; Werstiuk, E.; Hall, R.H. Conversion of $\mathrm{N}^{6}-\left(\Delta^{2}\right.$-Isopentenyl)Adenosine to Adenosine by Enzyme Activity in Tobacco Tissue. Plant Physiol. 1971, 48, 775-778. [CrossRef]

211. Houba-Hérin, N.; Pethe, C.; D'Alayer, J.; Laloue, M. Cytokinin Oxidase from Zea Mays: Purification, CDNA Cloning and Expression in Moss Protoplasts. Plant J. 1999, 17, 615-626. [CrossRef]

212. Morris, R.O.; Bilyeu, K.D.; Laskey, J.G.; Cheikh, N.N. Isolation of a Gene Encoding a Glycosylated Cytokinin Oxidase from Maize. Biochem. Biophys. Res. Commun. 1999, 255, 328-333. [CrossRef]

213. Galuszka, P.; Frébort, I.; Šebela, M.; Sauer, P.; Jacobsen, S.; Peč, P. Cytokinin Oxidase or Dehydrogenase? Mechanism of Cytokinin Degradation in Cereals. Eur. J. Biochem. 2001, 268, 450-461. [CrossRef]

214. Frébortová, J.; Novák, O.; Frébort, I.; Jorda, R. Degradation of Cytokinins by Maize Cytokinin Dehydrogenase Is Mediated by Free Radicals Generated by Enzymatic Oxidation of Natural Benzoxazinones. Plant J. 2010, 61, 467-481. [CrossRef]

215. Niemann, M.C.E.; Weber, H.; Hluska, T.; Leonte, G.; Anderson, S.M.; Novák, O.; Senes, A.; Werner, T. The Cytokinin Oxidase/Dehydrogenase CKX1 Is a Membrane-Bound Protein Requiring Homooligomerization in the Endoplasmic Reticulum for Its Cellular Activity. Plant Physiol. 2018, 176, 2024-2039. [CrossRef]

216. Frébortová, J.; Galuszka, P.; Werner, T.; Schmülling, T.; Frébort, I. Functional Expression and Purification of Cytokinin Dehydrogenase from Arabidopsis Thaliana (AtCKX2) in Saccharomyces Cerevisiae. Biol. Plant. 2007, 51, 673-682. [CrossRef]

217. Frébortová, J.; Greplová, M.; Seidl, M.F.; Heyl, A.; Frébort, I. Biochemical Characterization of Putative Adenylate Dimethylallyltransferase and Cytokinin Dehydrogenase from Nostoc sp. PCC 7120. PLoS ONE 2015, 10, e0138468. [CrossRef] [PubMed] 
218. Kowalska, M.; Galuszka, P.; Frébortová, J.; Šebela, M.; Béres, T.; Hluska, T.; Šmehilová, M.; Bilyeu, K.D.; Frébort, I. Vacuolar and Cytosolic Cytokinin Dehydrogenases of Arabidopsis Thaliana: Heterologous Expression, Purification and Properties. Phytochemistry 2010, 71, 1970-1978. [CrossRef] [PubMed]

219. Chatfield, J.M.; Armstrong, D.J. Regulation of Cytokinin Oxidase Activity in Callus Tissues of Phaseolus Vulgaris L. Cv Great Northern. Plant Physiol. 1986, 80, 493-499. [CrossRef] [PubMed]

220. Kamínek, M.; Armstrong, D.J. Genotypic Variation in Cytokinin Oxidase from Phaseolus Callus Cultures. Plant Physiol. 1990, 93, 1530-1538. [CrossRef] [PubMed]

221. Brugière, N.; Jiao, S.; Hantke, S.; Zinselmeier, C.; Roessler, J.A.; Niu, X.; Jones, R.J.; Habben, J.E. Cytokinin Oxidase Gene Expression in Maize Is Localized to the Vasculature, and Is Induced by Cytokinins, Abscisic Acid, and Abiotic Stress. Plant Physiol. 2003, 132, 1228-1240. [CrossRef]

222. Motyka, V.; Vaňková, R.; Čapková, V.; Petrášek, J.; Kamínek, M.; Schmülling, T. Cytokinin-Induced Upregulation of Cytokinin Oxidase Activity in Tobacco Includes Changes in Enzyme Glycosylation and Secretion. Physiol. Plant. 2003, 117, 11-21. [CrossRef]

223. Tsai, Y.-C.; Weir, N.R.; Hill, K.; Zhang, W.; Kim, H.J.; Shiu, S.-H.; Schaller, G.E.; Kieber, J.J. Characterization of Genes Involved in Cytokinin Signaling and Metabolism from Rice. Plant Physiol. 2012, 158, 1666-1684. [CrossRef]

224. Panda, B.B.; Sekhar, S.; Dash, S.K.; Behera, L.; Shaw, B.P. Biochemical and Molecular Characterisation of Exogenous Cytokinin Application on Grain Filling in Rice. BMC Plant Biol. 2018, 18, 89. [CrossRef]

225. Ashikari, M.; Sakakibara, H.; Lin, S.; Yamamoto, T.; Takashi, T.; Nishimura, A.; Angeles, E.R.; Qian, Q.; Kitano, H.; Matsuoka, M. Cytokinin Oxidase Regulates Rice Grain Production. Science 2005, 309, 741-745. [CrossRef]

226. Bartrina, I.; Otto, E.; Strnad, M.; Werner, T.; Schmülling, T. Cytokinin Regulates the Activity of Reproductive Meristems, Flower Organ Size, Ovule Formation, and Thus Seed Yield in Arabidopsis Thaliana. Plant Cell 2011, 23, 69-80. [CrossRef] [PubMed]

227. Zhang, L.; Zhao, Y.-L.; Gao, L.-F.; Zhao, G.-Y.; Zhou, R.-H.; Zhang, B.-S.; Jia, J.-Z. TaCKX6-D1, the Ortholog of Rice OsCKX2, Is Associated with Grain Weight in Hexaploid Wheat. New Phytol. 2012, 195, 574-584. [CrossRef]

228. Yeh, S.-Y.; Chen, H.-W.; Ng, C.-Y.; Lin, C.-Y.; Tseng, T.-H.; Li, W.-H.; Ku, M.S.B. Down-Regulation of Cytokinin Oxidase 2 Expression Increases Tiller Number and Improves Rice Yield. Rice 2015, 8, 36. [CrossRef] [PubMed]

229. Li, Y.; Song, G.; Gao, J.; Zhang, S.; Zhang, R.; Li, W.; Chen, M.; Liu, M.; Xia, X.; Risacher, T.; et al. Enhancement of Grain Number per Spike by RNA Interference of Cytokinin Oxidase 2 Gene in Bread Wheat. Hereditas 2018, 155, 33. [CrossRef]

230. Zhang, J.; Liu, W.; Yang, X.; Gao, A.; Li, X.; Wu, X.; Li, L. Isolation and Characterization of Two Putative Cytokinin Oxidase Genes Related to Grain Number per Spike Phenotype in Wheat. Mol. Biol. Rep. 2011, 38, 2337-2347. [CrossRef]

231. Mrízová, K.; Jiskrová, E.; Vyroubalová, Š.; Novák, O.; Ohnoutková, L.; Pospíšilová, H.; Frébort, I.; Harwood, W.A.; Galuszka, P. Overexpression of Cytokinin Dehydrogenase Genes in Barley (Hordeum Vulgare Cv. Golden Promise) Fundamentally Affects Morphology and Fertility. PLoS ONE 2013, 8, e79029. [CrossRef]

232. Werner, T.; Nehnevajova, E.; Köllmer, I.; Novák, O.; Strnad, M.; Krämer, U.; Schmülling, T. Root-Specific Reduction of Cytokinin Causes Enhanced Root Growth, Drought Tolerance, and Leaf Mineral Enrichment in Arabidopsis and Tobacco. Plant Cell 2010, 22, 3905-3920. [CrossRef]

233. Ramireddy, E.; Hosseini, S.A.; Eggert, K.; Gillandt, S.; Gnad, H.; von Wirén, N.; Schmülling, T. Root Engineering in Barley: Increasing Cytokinin Degradation Produces a Larger Root System, Mineral Enrichment in the Shoot and Improved Drought Tolerance. Plant Physiol. 2018, 177, 1078-1095. [CrossRef]

234. Gao, S.; Fang, J.; Xu, F.; Wang, W.; Sun, X.; Chu, J.; Cai, B.; Feng, Y.; Chu, C. CYTOKININ OXIDASE/DEHYDROGENASE4 Integrates Cytokinin and Auxin Signaling to Control Rice Crown Root Formation. Plant Physiol. 2014, 165, 1035-1046. [CrossRef]

235. Li, W.; Zhai, L.; Strauss, S.H.; Yer, H.; Merewitz, E.; Chen, J.; Wang, X.; Zhuang, W.; Fang, C.; Chen, Y.; et al. Transgenic Reduction of Cytokinin Levels in Roots Inhibits Root-Sprouting in Populus. Plant Physiol. 2019, 180, 1788-1792. [CrossRef]

236. Gao, S.; Xiao, Y.; Xu, F.; Gao, X.; Cao, S.; Zhang, F.; Wang, G.; Sanders, D.; Chu, C. Cytokinin-Dependent Regulatory Module Underlies the Maintenance of Zinc Nutrition in Rice. New Phytol. 2019, 224, 202-215. [CrossRef] [PubMed]

237. Vercruyssen, L.; Gonzalez, N.; Werner, T.; Schmülling, T.; Inzé, D. Combining Enhanced Root and Shoot Growth Reveals Cross Talk between Pathways That Control Plant Organ Size in Arabidopsis. Plant Physiol. 2011, 155, 1339-1352. [CrossRef] [PubMed]

238. Chen, L.; Zhao, J.; Song, J.; Jameson, P.E. Cytokinin Dehydrogenase: A Genetic Target for Yield Improvement in Wheat. Plant Biotechnol. J. 2020, 18, 614-630. [CrossRef] [PubMed]

239. Heyl, A.; Brault, M.; Frugier, F.; Kuderová, A.; Lindner, A.-C.; Motyka, V.; Rashotte, A.M.; von Schwartzenberg, K.; Vaňková, R.; Schaller, G.E. Nomenclature for Members of the Two-Component Signaling Pathway of Plants. Plant Physiol. 2013, 161, 1063-1065. [CrossRef] [PubMed]

240. Keshishian, E.A.; Rashotte, A.M. Plant Cytokinin Signalling. Essays Biochem. 2015, 58, 13-27. [CrossRef]

241. Hothorn, M.; Dabi, T.; Chory, J. Structural Basis for Cytokinin Recognition by Arabidopsis Thaliana Histidine Kinase 4. Nat. Chem. Biol. 2011, 7, 766-768. [CrossRef]

242. Steklov, M.Y.; Lomin, S.N.; Osolodkin, D.I.; Romanov, G.A. Structural Basis for Cytokinin Receptor Signaling: An Evolutionary Approach. Plant Cell Rep. 2013, 32, 781-793. [CrossRef]

243. Upadhyay, A.A.; Fleetwood, A.D.; Adebali, O.; Finn, R.D.; Zhulin, I.B. Cache Domains That Are Homologous to, but Different from PAS Domains Comprise the Largest Superfamily of Extracellular Sensors in Prokaryotes. PLoS Comput. Biol. $2016,12$. [CrossRef] 
244. Wang, F.-F.; Cheng, S.-T.; Wu, Y.; Ren, B.-Z.; Qian, W. A Bacterial Receptor PcrK Senses the Plant Hormone Cytokinin to Promote Adaptation to Oxidative Stress. Cell Rep. 2017, 21, 2940-2951. [CrossRef]

245. Mähönen, A.P.; Higuchi, M.; Törmäkangas, K.; Miyawaki, K.; Pischke, M.S.; Sussman, M.R.; Helariutta, Y.; Kakimoto, T. Cytokinins Regulate a Bidirectional Phosphorelay Network in Arabidopsis. Curr. Biol. CB 2006, 16, 1116-1122. [CrossRef]

246. Caesar, K.; Thamm, A.M.K.; Witthöft, J.; Elgass, K.; Huppenberger, P.; Grefen, C.; Horak, J.; Harter, K. Evidence for the Localization of the Arabidopsis Cytokinin Receptors AHK3 and AHK4 in the Endoplasmic Reticulum. J. Exp. Bot. 2011, 62, 5571-5580. [CrossRef] [PubMed]

247. Wulfetange, K.; Lomin, S.N.; Romanov, G.A.; Stolz, A.; Heyl, A.; Schmülling, T. The Cytokinin Receptors of Arabidopsis Are Located Mainly to the Endoplasmic Reticulum. Plant Physiol. 2011, 156, 1808-1818. [CrossRef] [PubMed]

248. Romanov, G.A.; Lomin, S.N.; Schmülling, T. Cytokinin Signaling: From the ER or from the PM? That Is the Question! New Phytol. 2018. [CrossRef] [PubMed]

249. Lomin, S.N.; Savelieva, E.M.; Arkhipov, D.V.; Romanov, G.A. Evidences for Preferential Localization of Cytokinin Receptors of Potato in the Endoplasmic Reticulum. Biochem. Mosc. Suppl. Ser. Membr. Cell Biol. 2020, 14, 146-153. [CrossRef]

250. Grignon, C.; Sentenac, H. PH and Ionic Conditions in the Apoplast. Ann. Rev. Plant Physiol. Plant. Mol. Biol. 1991, 42, 103-128. [CrossRef]

251. Geilfus, C.-M. The PH of the Apoplast: Dynamic Factor with Functional Impact under Stress. Mol. Plant. 2017, 10, 1371-1386. [CrossRef] [PubMed]

252. Jia, W.; Davies, W.J. Modification of Leaf Apoplastic PH in Relation to Stomatal Sensitivity to Root-Sourced Abscisic Acid Signals. Plant Physiol. 2007, 143, 68-77. [CrossRef]

253. Antoniadi, I.; Novák, O.; Gelová, Z.; Johnson, A.; Plíhal, O.; Simerský, R.; Mik, V.; Vain, T.; Mateo-Bonmatí, E.; Karady, M.; et al. Cell-Surface Receptors Enable Perception of Extracellular Cytokinins. Nat. Commun. 2020, 11, 4284. [CrossRef]

254. Jaworek, P.; Tarkowski, P.; Hluska, T.; Kouřil, Š.; Vrobel, O.; Nisler, J.; Kopečný, D. Characterization of Five CHASE-Containing Histidine Kinase Receptors from Populus $\times$ Canadensis Cv. Robusta Sensing Isoprenoid and Aromatic Cytokinins. Planta 2019, $251,1$. [CrossRef]

255. Zürcher, E.; Liu, J.; di Donato, M.; Geisler, M.; Müller, B. Plant Development Regulated by Cytokinin Sinks. Science 2016, 353, 1027-1030. [CrossRef]

256. Zalabák, D.; Johnová, P.; Plíhal, O.; Šenková, K.; Šamajová, O.; Jiskrová, E.; Novák, O.; Jackson, D.; Mohanty, A.; Galuszka, P. Maize Cytokinin Dehydrogenase Isozymes Are Localized Predominantly to the Vacuoles. Plant Physiol. Biochem. 2016, 104, 114-124. [CrossRef] [PubMed]

257. Gelová, Z.; Ten Hoopen, P.; Novák, O.; Motyka, V.; Pernisová, M.; Dabravolski, S.; Didi, V.; Tillack, I.; Oklešt’ková, J.; Strnad, M.; et al. Antibody-Mediated Modulation of Cytokinins in Tobacco: Organ-Specific Changes in Cytokinin Homeostasis. J. Exp. Bot. 2018, 69, 441-454. [CrossRef] [PubMed]

258. Kubiasová, K.; Montesinos, J.C.; Šamajová, O.; Nisler, J.; Mik, V.; Semerádová, H.; Plíhalová, L.; Novák, O.; Marhavý, P.; Cavallari, N.; et al. Cytokinin Fluoroprobe Reveals Multiple Sites of Cytokinin Perception at Plasma Membrane and Endoplasmic Reticulum. Nat. Commun. 2020, 11, 4285. [CrossRef]

259. Marhavý, P.; Bielach, A.; Abas, L.; Abuzeineh, A.; Duclercq, J.; Tanaka, H.; Pařezová, M.; Petrášek, J.; Friml, J.; Kleine-Vehn, J.; et al. Cytokinin Modulates Endocytic Trafficking of PIN1 Auxin Efflux Carrier to Control Plant Organogenesis. Dev. Cell 2011, 21, 796-804. [CrossRef] [PubMed]

260. Gupta, R.; Pizarro, L.; Leibman-Markus, M.; Marash, I.; Bar, M. Cytokinin Response Induces Immunity and Fungal Pathogen Resistance, and Modulates Trafficking of the PRR LeEIX2 in Tomato. Mol. Plant Pathol. 2020. [CrossRef]

261. Dortay, H.; Mehnert, N.; Bürkle, L.; Schmülling, T.; Heyl, A. Analysis of Protein Interactions within the Cytokinin-Signaling Pathway of Arabidopsis Thaliana. FEBS J. 2006, 273, 4631-4644. [CrossRef]

262. Lomin, S.N.; Myakushina, Y.A.; Arkhipov, D.V.; Leonova, O.G.; Popenko, V.I.; Schmülling, T.; Romanov, G.A. Studies of Cytokinin Receptor-Phosphotransmitter Interaction Provide Evidences for the Initiation of Cytokinin Signalling in the Endoplasmic Reticulum. Funct. Plant. Biol. FPB 2018, 45, 192-202. [CrossRef]

263. Kudla, J.; Bock, R. Lighting the Way to Protein-Protein Interactions: Recommendations on Best Practices for Bimolecular Fluorescence Complementation Analyses. Plant Cell 2016, 28, 1002-1008. [CrossRef]

264. Capra, E.J.; Laub, M.T. Evolution of Two-Component Signal Transduction Systems. Ann. Rev. Microbiol. 2012, 66, 325-347. [CrossRef]

265. Samanovic, M.I.; Hsu, H.-C.; Jones, M.B.; Jones, V.; McNeil, M.R.; Becker, S.H.; Jordan, A.T.; Strnad, M.; Xu, C.; Jackson, M.; et al. Cytokinin Signaling in Mycobacterium Tuberculosis. mBio 2018, 9. [CrossRef]

266. Hutchison, C.E.; Li, J.; Argueso, C.; Gonzalez, M.; Lee, E.; Lewis, M.W.; Maxwell, B.B.; Perdue, T.D.; Schaller, G.E.; Alonso, J.M.; et al. The Arabidopsis Histidine Phosphotransfer Proteins Are Redundant Positive Regulators of Cytokinin Signaling. Plant Cell 2006, 18, 3073-3087. [CrossRef] [PubMed]

267. Punwani, J.A.; Kieber, J.J. Localization of the Arabidopsis Histidine Phosphotransfer Proteins Is Independent of Cytokinin. Plant Signal. Behav. 2010, 5, 896-898. [CrossRef] [PubMed]

268. Mähönen, A.P.; Bishopp, A.; Higuchi, M.; Nieminen, K.M.; Kinoshita, K.; Törmäkangas, K.; Ikeda, Y.; Oka, A.; Kakimoto, T.; Helariutta, Y. Cytokinin Signaling and Its Inhibitor AHP6 Regulate Cell Fate during Vascular Development. Science 2006, 311, 94-98. [CrossRef] 
269. Müller, B. Generic Signal-Specific Responses: Cytokinin and Context-Dependent Cellular Responses. J. Exp. Bot. 2011, 62, 3273-3288. [CrossRef] [PubMed]

270. Argyros, R.D.; Mathews, D.E.; Chiang, Y.-H.; Palmer, C.M.; Thibault, D.M.; Etheridge, N.; Argyros, D.A.; Mason, M.G.; Kieber, J.J.; Schaller, G.E. Type B Response Regulators of Arabidopsis Play Key Roles in Cytokinin Signaling and Plant Development. Plant Cell 2008, 20, 2102-2116. [CrossRef]

271. Rashotte, A.M.; Carson, S.D.B.; To, J.P.C.; Kieber, J.J. Expression Profiling of Cytokinin Action in Arabidopsis. Plant Physiol. 2003, 132, 1998-2011. [CrossRef]

272. Kiba, T.; Aoki, K.; Sakakibara, H.; Mizuno, T. Arabidopsis Response Regulator, ARR22, Ectopic Expression of Which Results in Phenotypes Similar to the Wol Cytokinin-Receptor Mutant. Plant Cell Physiol. 2004, 45, 1063-1077. [CrossRef]

273. Gattolin, S.; Alandete-Saez, M.; Elliott, K.; Gonzalez-Carranza, Z.; Naomab, E.; Powell, C.; Roberts, J.A. Spatial and Temporal Expression of the Response Regulators ARR22 and ARR24 in Arabidopsis Thaliana. J. Exp. Bot. 2006, 57, 4225-4233. [CrossRef] [PubMed]

274. Rashotte, A.M.; Mason, M.G.; Hutchison, C.E.; Ferreira, F.J.; Schaller, G.E.; Kieber, J.J. A Subset of Arabidopsis AP2 Transcription Factors Mediates Cytokinin Responses in Concert with a Two-Component Pathway. Proc. Natl. Acad. Sci. USA 2006, 103, 11081-11085. [CrossRef]

275. Rashotte, A.M.; Goertzen, L.R. The CRF Domain Defines Cytokinin Response Factor Proteins in Plants. BMC Plant Biol. 2010, 10, 74. [CrossRef] [PubMed]

276. Cutcliffe, J.W.; Hellmann, E.; Heyl, A.; Rashotte, A.M. CRFs Form Protein-Protein Interactions with Each Other and with Members of the Cytokinin Signalling Pathway in Arabidopsis via the CRF Domain. J. Exp. Bot. 2011, 62, 4995-5002. [CrossRef] [PubMed]

277. Zwack, P.J.; Shi, X.; Robinson, B.R.; Gupta, S.; Compton, M.A.; Gerken, D.M.; Goertzen, L.R.; Rashotte, A.M. Vascular Expression and C-Terminal Sequence Divergence of Cytokinin Response Factors in Flowering Plants. Plant Cell Physiol. 2012, 53, 1683-1695. [CrossRef] [PubMed]

278. Shi, X.; Gupta, S.; Rashotte, A.M. Solanum Lycopersicum Cytokinin Response Factor (SlCRF) Genes: Characterization of CRF Domain-Containing ERF Genes in Tomato. J. Exp. Bot. 2012, 63, 973-982. [CrossRef] [PubMed]

279. Zwack, P.J.; Robinson, B.R.; Risley, M.G.; Rashotte, A.M. Cytokinin Response Factor 6 Negatively Regulates Leaf Senescence and Is Induced in Response to Cytokinin and Numerous Abiotic Stresses. Plant Cell Physiol. 2013, 54, 971-981. [CrossRef]

280. Zwack, P.J.; De Clercq, I.; Howton, T.C.; Hallmark, H.T.; Hurny, A.; Keshishian, E.A.; Parish, A.M.; Benkova, E.; Mukhtar, M.S.; Van Breusegem, F.; et al. Cytokinin Response Factor 6 Represses Cytokinin-Associated Genes during Oxidative Stress. Plant Physiol. 2016, 172, 1249-1258. [CrossRef]

281. Zwack, P.J.; Compton, M.A.; Adams, C.I.; Rashotte, A.M. Cytokinin Response Factor 4 (CRF4) Is Induced by Cold and Involved in Freezing Tolerance. Plant Cell Rep. 2016, 35, 573-584. [CrossRef]

282. Jeon, J.; Cho, C.; Lee, M.R.; Van Binh, N.; Kim, J. CYTOKININ RESPONSE FACTOR2 (CRF2) and CRF3 Regulate Lateral Root Development in Response to Cold Stress in Arabidopsis. Plant Cell 2016, 28, 1828-1843. [CrossRef]

283. Qin, L.; Wang, L.; Guo, Y.; Li, Y.; Ümüt, H.; Wang, Y. An ERF Transcription Factor from Tamarix Hispida, ThCRF1, Can Adjust Osmotic Potential and Reactive Oxygen Species Scavenging Capability to Improve Salt Tolerance. Plant Sci. Int. J. Exp. Plant. Biol. 2017, 265, 154-166. [CrossRef]

284. Melton, A.E.; Zwack, P.J.; Rashotte, A.M.; Goertzen, L.R. Identification and Functional Characterization of the Marshallia (Asteraceae) Clade III Cytokinin Response Factor (CRF). Plant Signal. Behav. 2019, 1-6. [CrossRef]

285. Chevalier, F.; Perazza, D.; Laporte, F.; Le Hénanff, G.; Hornitschek, P.; Bonneville, J.-M.; Herzog, M.; Vachon, G. GeBP and GeBP-like Proteins Are Noncanonical Leucine-Zipper Transcription Factors That Regulate Cytokinin Response in Arabidopsis. Plant Physiol. 2008, 146, 1142-1154. [CrossRef]

286. Takei, K.; Sakakibara, H.; Taniguchi, M.; Sugiyama, T. Nitrogen-Dependent Accumulation of Cytokinins in Root and the Translocation to Leaf: Implication of Cytokinin Species That Induces Gene Expression of Maize Response Regulator. Plant Cell Physiol. 2001, 42, 85-93. [CrossRef] [PubMed]

287. Weiler, E.W.; Ziegler, H. Determination of Phytohormones in Phloem Exudate from Tree Species by Radioimmunoassay. Planta 1981, 152, 168-170. [CrossRef] [PubMed]

288. Alvarez, S.; Marsh, E.L.; Schroeder, S.G.; Schachtman, D.P. Metabolomic and Proteomic Changes in the Xylem Sap of Maize under Drought. Plant Cell Environ. 2008, 31, 325-340. [CrossRef] [PubMed]

289. Field, S.K.; Smith, J.P.; Morrison, E.N.; Emery, R.J.N.; Holzapfel, B.P. Soil Temperature Prior to Veraison Alters Grapevine Carbon Partitioning, Xylem Sap Hormones, and Fruit Set. Am. J. Enol. Vitic. 2019. [CrossRef]

290. Foo, E.; Morris, S.E.; Parmenter, K.; Young, N.; Wang, H.; Jones, A.; Rameau, C.; Turnbull, C.G.N.; Beveridge, C.A. Feedback Regulation of Xylem Cytokinin Content Is Conserved in Pea and Arabidopsis. Plant Physiol. 2007, 143, 1418-1428. [CrossRef]

291. Matsumoto-Kitano, M.; Kusumoto, T.; Tarkowski, P.; Kinoshita-Tsujimura, K.; Václavíková, K.; Miyawaki, K.; Kakimoto, T. Cytokinins Are Central Regulators of Cambial Activity. Proc. Natl. Acad. Sci. USA 2008, 105, 20027-20031. [CrossRef]

292. Zhang, R.; Letham, D.S.; Willcocks, D.A. Movement to Bark and Metabolism of Xylem Cytokinins in Stems of Lupinus Angustifolius. Phytochemistry 2002, 60, 483-488. [CrossRef]

293. Gillissen, B.; Bürkle, L.; André, B.; Kühn, C.; Rentsch, D.; Brandl, B.; Frommer, W.B. A New Family of High-Affinity Transporters for Adenine, Cytosine, and Purine Derivatives in Arabidopsis. Plant Cell 2000, 12, 291-300. [CrossRef] 
294. Bürkle, L.; Cedzich, A.; Döpke, C.; Stransky, H.; Okumoto, S.; Gillissen, B.; Kühn, C.; Frommer, W.B. Transport of Cytokinins Mediated by Purine Transporters of the PUP Family Expressed in Phloem, Hydathodes, and Pollen of Arabidopsis. Plant J. Cell Mol. Biol. 2003, 34, 13-26. [CrossRef]

295. Xiao, Y.; Liu, D.; Zhang, G.; Gao, S.; Liu, L.; Xu, F.; Che, R.; Wang, Y.; Tong, H.; Chu, C. Big Grain3, Encoding a Purine Permease, Regulates Grain Size via Modulating Cytokinin Transport in Rice. J. Integr. Plant Biol. 2019, 61, 581-597. [CrossRef]

296. Pastor-Anglada, M.; Pérez-Torras, S. Who Is Who in Adenosine Transport. Front. Pharmacol. 2018, 9, 627. [CrossRef] [PubMed]

297. Hirose, N.; Makita, N.; Yamaya, T.; Sakakibara, H. Functional Characterization and Expression Analysis of a Gene, OsENT2, Encoding an Equilibrative Nucleoside Transporter in Rice Suggest a Function in Cytokinin Transport. Plant Physiol. 2005, 138, 196-206. [CrossRef] [PubMed]

298. Sun, J.; Hirose, N.; Wang, X.; Wen, P.; Xue, L.; Sakakibara, H.; Zuo, J. Arabidopsis SOI33/AtENT8 Gene Encodes a Putative Equilibrative Nucleoside Transporter That Is Involved in Cytokinin Transport In Planta. J. Integr. Plant Biol. 2005, 47, 588-603. [CrossRef]

299. Wormit, A.; Traub, M.; Flörchinger, M.; Neuhaus, H.E.; Möhlmann, T. Characterization of Three Novel Members of the Arabidopsis Thaliana Equilibrative Nucleoside Transporter (ENT) Family. Biochem. J. 2004, 383, 19-26. [CrossRef] [PubMed]

300. Kudo, T.; Kiba, T.; Sakakibara, H. Metabolism and Long-Distance Translocation of Cytokinins. J. Integr. Plant Biol. 2010, 52, 53-60. [CrossRef]

301. Zhang, K.; Novák, O.; Wei, Z.; Gou, M.; Zhang, X.; Yu, Y.; Yang, H.; Cai, Y.; Strnad, M.; Liu, C.-J. Arabidopsis ABCG14 Protein Controls the Acropetal Translocation of Root-Synthesized Cytokinins. Nat. Commun. 2014, 5, 3274. [CrossRef]

302. Ko, D.; Kang, J.; Kiba, T.; Park, J.; Kojima, M.; Do, J.; Kim, K.Y.; Kwon, M.; Endler, A.; Song, W.-Y.; et al. Arabidopsis ABCG14 Is Essential for the Root-to-Shoot Translocation of Cytokinin. Proc. Natl. Acad. Sci. USA 2014, 111, 7150-7155. [CrossRef]

303. Zhao, J.; Yu, N.; Ju, M.; Fan, B.; Zhang, Y.; Zhu, E.; Zhang, M.; Zhang, K. ABC Transporter OsABCG18 Controls the Shootward Transport of Cytokinins and Grain Yield in Rice. J. Exp. Bot. 2019, 70, 6277-6291. [CrossRef]

304. Feng, Y.; Sun, Q.; Zhang, G.; Wu, T.; Zhang, X.; Xu, X.; Han, Z.; Wang, Y. Genome-Wide Identification and Characterization of ABC Transporters in Nine Rosaceae Species Identifying MdABCG28 as a Possible Cytokinin Transporter Linked to Dwarfing. Int. J. Mol. Sci. 2019, 20, 5783. [CrossRef]

305. Poitout, A.; Crabos, A.; Petř́ík, I.; Novák, O.; Krouk, G.; Lacombe, B.; Ruffel, S. Responses to Systemic Nitrogen Signaling in Arabidopsis Roots Involve Trans-Zeatin in Shoots. Plant Cell 2018, 30, 1243-1257. [CrossRef]

306. Kim, A.; Chen, J.; Khare, D.; Jin, J.-Y.; Yamaoka, Y.; Maeshima, M.; Zhao, Y.; Martinoia, E.; Hwang, J.-U.; Lee, Y. Non-Intrinsic ATP-Binding Cassette Proteins ABCI19, ABCI20 and ABCI21 Modulate Cytokinin Response at the Endoplasmic Reticulum in Arabidopsis Thaliana. Plant Cell Rep. 2020. [CrossRef] [PubMed]

307. Laplaze, L.; Benková, E.; Casimiro, I.; Maes, L.; Vanneste, S.; Swarup, R.; Weijers, D.; Calvo, V.; Parizot, B.; Herrera-Rodriguez, M.B.; et al. Cytokinins Act Directly on Lateral Root Founder Cells to Inhibit Root Initiation. Plant Cell 2007, 19, 3889-3900. [CrossRef]

308. Tessi, T.M.; Brumm, S.; Winklbauer, E.; Schumacher, B.; Pettinari, G.; Lescano, I.; González, C.A.; Wanke, D.; Maurino, V.G.; Harter, K.; et al. Arabidopsis AZG2 Transports Cytokinins in Vivo and Regulates Lateral Root Emergence. New Phytol. 2020. [CrossRef] [PubMed]

309. Tessi, T.M.; Shahriari, M.; Maurino, V.G.; Meissner, E.; Novák, O.; Pasternak, T.; Schumacher, B.S.; Flubacher, N.S.; Nautscher, M.; Williams, A.; et al. The Auxin Transporter PIN1 and the Cytokinin Transporter AZG1 Interact to Regulate the Root Stress Response. bioRxiv 2020. [CrossRef]

310. Mansfield, T.A.; Schultes, N.P.; Mourad, G.S. AtAzg1 and AtAzg2 Comprise a Novel Family of Purine Transporters in Arabidopsis. FEBS Lett. 2009, 583, 481-486. [CrossRef] [PubMed] 